\title{
Non-Coding RNAs: Uncharted Mediators of Thyroid Cancer Pathogenesis
}

\author{
Hossein Tabatabaeian ${ }^{1}$, Samantha Peiling Yang $2,3, * \mathbb{1}$ and Yvonne Tay ${ }^{1,4, *}$ \\ 1 Cancer Science Institute of Singapore, National University of Singapore, Singapore 117599, Singapore; \\ csiht@nus.edu.sg \\ 2 Endocrinology Division, Department of Medicine, National University Hospital, Singapore 119228, Singapore \\ 3 Department of Medicine, Yong Loo Lin School of Medicine, National University of Singapore, \\ Singapore 117597, Singapore \\ 4 Department of Biochemistry, Yong Loo Lin School of Medicine, National University of Singapore, \\ Singapore 117597, Singapore \\ * Correspondence: mdcyp@nus.edu.sg (S.P.Y.); yvonnetay@nus.edu.sg (Y.T.)
}

Received: 5 October 2020; Accepted: 2 November 2020; Published: 4 November 2020

Simple Summary: Thyroid cancer is the most common type of endocrine system malignancy. The effective diagnosis, precise treatment, and better short and long-term prognosis of thyroid cancer patients have remained challenging. Non-coding RNAs (ncRNAs) are emerging molecules with diverse capabilities in initiating and promoting thyroid cancer upon dysregulation. The expression profile of these molecules could be used to detect thyroid cancer, determine the therapeutic approaches, and predict the patients' survival. Thus, ncRNAs could have clinical significance in precision medicine.

\begin{abstract}
Thyroid cancer is the most prevalent malignancy of the endocrine system and the ninth most common cancer globally. Despite the advances in the management of thyroid cancer, there are critical issues with the diagnosis and treatment of thyroid cancer that result in the poor overall survival of undifferentiated and metastatic thyroid cancer patients. Recent studies have revealed the role of different non-coding RNAs (ncRNAs), such as microRNAs (miRNAs), long non-coding RNAs (lncRNAs) and circular RNAs (circRNAs) that are dysregulated during thyroid cancer development or the acquisition of resistance to therapeutics, and may play key roles in treatment failure and poor prognosis of the thyroid cancer patients. Here, we systematically review the emerging roles and molecular mechanisms of ncRNAs that regulate thyroid tumorigenesis and drug response. We then propose the potential clinical implications of ncRNAs as novel diagnostic and prognostic biomarkers for thyroid cancer.
\end{abstract}

Keywords: thyroid carcinoma; non-coding RNA; radioactive iodine; drug resistance; prognosis

\section{Introduction}

Thyroid carcinoma is the most prevalent malignancy of the endocrine system with a significantly higher incidence in women [1-3] and is the 9th most common cancer globally [3]. The incidence of thyroid cancer has been escalating worldwide in recent years [2,4]. According to the Surveillance, Epidemiology and End Results (SEER) Program [5], 53,000 newly diagnosed cases of thyroid cancer are anticipated in the United States in 2020 and these will represent $2.9 \%$ of all new cancer cases. Globally, there were newly diagnosed 567,233 thyroid cancer cases in 2018 that comprise $3.1 \%$ of all cancer incidences [3]. The cause of this rise in incidence is multi-factorial. It is partially contributed by the detection of incidental thyroid cancers with the increasing use of cross-sectional imaging. However, other factors likely play a role in the pathogenesis of these thyroid cancer cases. The well-described risk 
factors of thyroid cancer are exposure to ionizing radiation, particularly in childhood, and family history of thyroid cancer. The potential role of other factors such as smoking, obesity, hormonal exposures, and environmental toxins/ endocrine-disrupting chemicals have been implicated [6]. Their mechanistic role in the pathogenesis of thyroid cancer has not been well-elucidated. Further environmental and biomolecular studies will be essential to better understand the complex etiology of thyroid cancer [7].

The thyroid gland comprises two specific cell types. Thyroid follicular (epithelial) cells produce and secrete the thyroid hormones, thereby regulating the body's temperature, metabolism, and heart rate. The second cell type is parafollicular cells ( $C$ cells) that reside in the thyroid connective tissue and are responsible for calcitonin secretion to regulate the levels of calcium and phosphate in the body $[8,9]$. Thyroid cancer is classified into four types based on histopathological analysis and site of origin: (1) papillary thyroid carcinoma (PTC) that accounts for $80 \%$ of all cases and commonly metastasize to cervical lymph nodes. (2) Follicular thyroid carcinoma (FTC) represents $10 \%$ of all cases and the widely invasive sub-type has a tendency for metastasis to distant sites, whereas its minimally invasive sub-type has an overall low risk of recurrence and metastasis. (3) Medullary thyroid carcinoma (MTC) that is more aggressive than PTC and FTC, has higher metastatic rates to cervical lymph nodes and distant sites, and occurs in $4 \%$ of thyroid cancer cases. (4) Poorly differentiated thyroid carcinoma (PDTC) and anaplastic thyroid carcinoma (ATC) are the most aggressive and least differentiated types of thyroid carcinoma with the highest rate of spread to other organs. PDTC and ATC account for $5-10 \%$ of follicular thyroid cancers $[1,10,11]$. Among these types, PTC, FTC, PDTC and ATC originate from follicular cells, whereas MTC develops from C cells.

The main measure to detect thyroid cancer is ultrasound, which can be complemented with radioiodine scanning and fine-needle aspiration (FNA) biopsy [12]; and the treatment for thyroid cancer is surgical excision [13]. Post-surgery, other therapeutic strategies including radioactive iodine (RAI) therapy, and systemic therapies might be incorporated into the treatment regime for patients with high risk of recurrent or persistent disease [14]. Improvements in detection and treatment strategies have improved the survival of thyroid cancer. According to the American Society of Clinical Oncology, the 5-year survival for most of the non-metastatic thyroid cancer types is above $95 \%$, whereas this rate falls drastically to $31 \%$ for ATC. In metastatic thyroid cancer, however, the 5-year survival rate for PTC, FTC and MTC drops to 78, 63 and 39\%, respectively. The 5-year survival rate for metastatic ATC cases is only $4 \%$. These data indicate that there is room for improvement in the current measures for thyroid cancer management, especially for more aggressive subtypes, and highlight the need to identify specific molecular diagnostic/prognostic biomarkers for personalized medicine.

Current diagnostic biomarkers in thyroid cancer include point mutations in the BRAF, NRAS, KRAS, HRAS genes, and rearrangements in paired box 8 (PAX8)/peroxisome proliferator-activated receptor gamma (PPARG) and RET [15-18]. In addition, mutations within the telomerase reverse transcriptase (TERT) promoter region have been detected more frequently in aggressive thyroid cancer cases [19]. Notwithstanding, the present molecular testing of thyroid cancer is chiefly useful to stratify indeterminate nodules, thereby to avoid surgery or prevent unnecessary repeated FNA [20]. The identification of novel molecular biomarkers to facilitate early diagnosis and predict drug responsiveness would be invaluable to improve the survival rate and quality of life for thyroid cancer patients. Non-coding RNAs (ncRNAs) are fast emerging as novel functional molecules and also biomarkers in human cancers [21-24]. Around $98 \%$ of the transcriptome in human cells corresponds to ncRNAs that are transcribed from previously considered "junk DNA" sequences such as introns and intergenic nucleotides [25]. These non-protein-coding transcripts are classified as small ncRNAs (sncRNAs) and long non-coding RNAs (lncRNAs) that are less than or more than 200 nucleotides in length, respectively. sncRNAs comprise small nuclear RNAs (snRNAs), microRNAs (miRNAs), piwi interacting RNAs (piRNAs) and small nucleolar RNAs (snoRNAs) [26-30]. However, circular RNAs (circRNAs) belong to both sncRNA and lncRNA classifications due to their variable length, ranging from 100-10,000 nucleotides [31]. The majority of human miRNAs and circRNAs are transcribed from introns, reflecting the importance of non-coding DNA sequences in determining 
cell fate [32]. Compelling evidence highlights the involvement of ncRNAs in almost all physiological and biological cell processes, such as cell growth, proliferation, senescence, apoptosis, invasion, migration, angiogenesis and inflammation [22,33-38]. ncRNAs impose their functions through different mechanisms—summarized in the following sections and Figure 1.

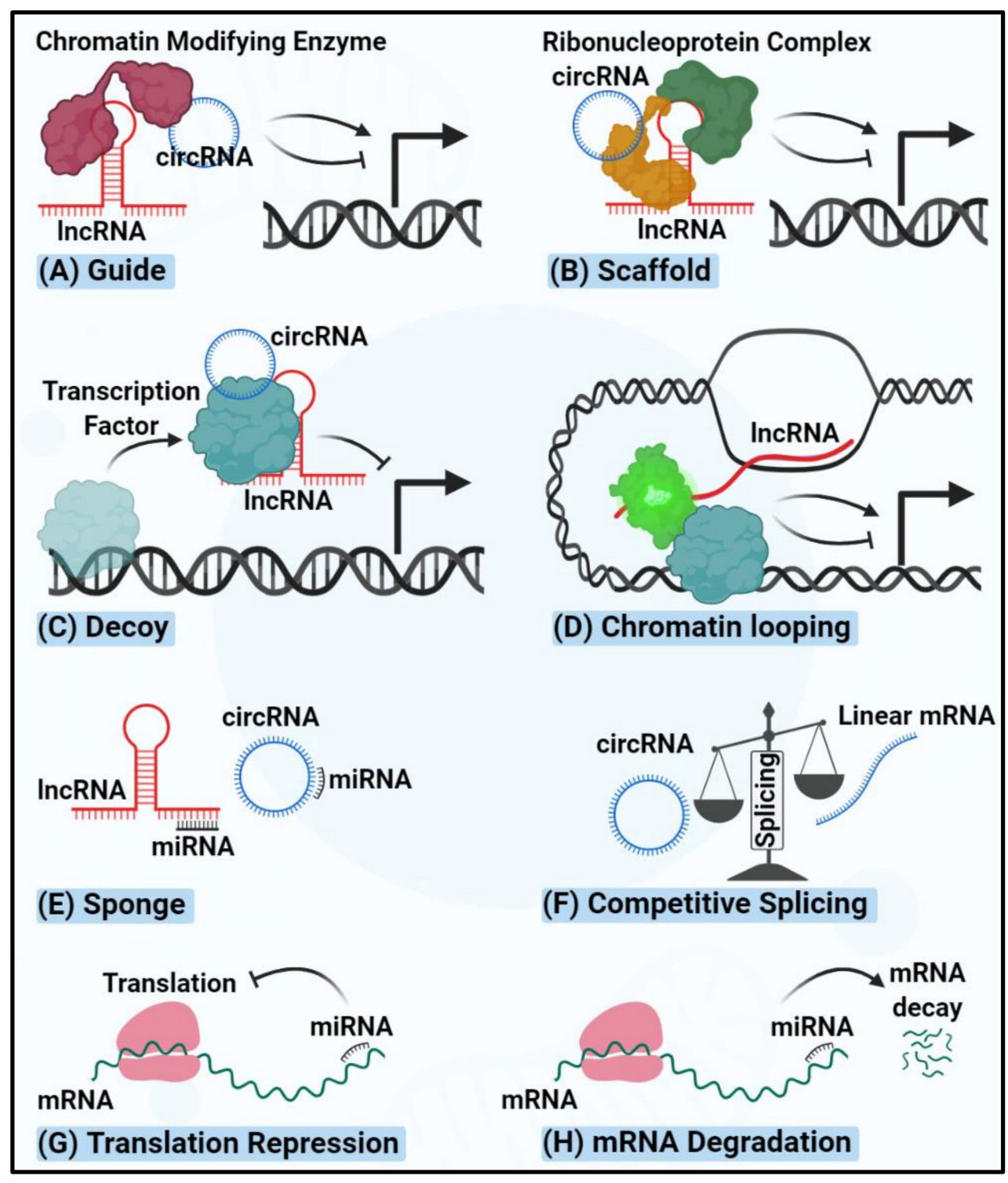

Figure 1. The schematic of mechanisms of action of ncRNAs. (A) lncRNAs and circRNAs can guide chromatin remodeling factors to either activate or repress the transcription of target genes. (B) lncRNAs and circRNAs, as scaffolds, can facilitate the assembly of ribonucleoprotein complexes to either activate or repress the transcription of target genes. (C) lncRNAs and circRNAs can sponge the transcription factors to repress the transcription of the target genes. (D) Upon transcription, lncRNAs can facilitate the formation of regulatory complexes and loop the DNA, thereby priming long-range gene transcription. (E) lncRNAs and circRNAs can sponge the miRNAs, thereby rescuing the miRNA target transcripts. (F) circRNAs can compete with the linear mRNA(s) transcribed from their host gene and repress the canonical splicing over the back splicing. (G) miRNAs bind to their target mRNAs and repress the translation efficiency upon non-perfect complementation between the seed region and targeted binding site. (H) miRNAs bind to their target mRNAs and result in transcript degradation upon perfect complementation between the seed region and targeted binding site. 
Upon dysregulation, oncogenic and tumor suppressor ncRNAs could drive cancer initiation and progression, and/or alter drug response [39-41]. This review systematically focuses on the recent advances in the molecular roles of different ncRNA classes in thyroid cancer, as well as their implications as diagnostic and prognostic biomarkers and therapeutic targets.

\section{2. miRNAs Regulating Thyroid Carcinogenesis}

miRNAs are a subclass of sncRNAs with about 19-24 nucleotides in length that mainly regulate gene expression at the post-transcriptional level. miRNAs bind to miRNA response elements on target protein-coding and non-coding transcripts to regulate their expression. miRNA binding may lead to mRNA degradation or translational repression, depending on the extent of complementarity with each target region [42-44] (Figure 1). miRNAs have also been shown to regulate genes transcriptionally via interacting with lncRNAs, leading to the up or down-regulation of target genes [45-47]. The impact of miRNA dysregulation on cancer was first described by Calin et al. in 2002 [48]. Shortly after, He et al. showed the up-regulation of miR-221, miR-222, and miR-146 in PTC patients, which are the first dysregulated miRNAs reported in thyroid cancer [49]. To date, many additional studies have identified miRNAs involved in thyroid cancer initiation and progression [50,51]. Here, we summarize the recent list of dysregulated miRNAs in thyroid cancer, published from 2015 onward, with implications in cancer initiation and progression, briefly listed in Table 1.

A group of dysregulated miRNAs has been shown by in vitro and in vivo assays to inhibit apoptosis and promote proliferation, invasion and migration in thyroid cancer. For instance, the down-regulation of miR-524-5p [68], miR-141-3p [61], miR-9 [67], miR-199b-5p [66], miR-1266 [60], miR-144 [62], miR-150 [64] and miR-7 [69] were demonstrated to play pivotal roles in thyroid tumorigenesis. However, there is lack of inclusive data to know how these alterations could mechanistically impose tumorigenic properties in the context of thyroid cancer. Despite this ambiguity, the dysregulation of some other miRNAs has been reported to promote thyroid carcinomas via different signaling pathways, such as Wnt and phosphatidylinositol-4,5-Bisphosphate 3-Kinase $\left(\mathrm{PI}_{3} \mathrm{~K}\right) /$ Akt (Figure 2). 
Table 1. Dysregulated miRNAs in thyroid cancer.

\begin{tabular}{|c|c|c|c|c|c|}
\hline miRNA & Alteration & Mechanism & Thyroid Cancer Type & Sample & Ref. \\
\hline $\operatorname{miR}-146 a / b-5 p$ & \multirow{6}{*}{$\uparrow$} & $\downarrow$ RAR- $\beta$ & PTC & \multirow{5}{*}{ Cell line and tissue } & [52] \\
\hline miR-155 & & $\downarrow$ SOCS1 & ATC & & [53] \\
\hline miR-21 & & $\downarrow \mathrm{VHL} \rightarrow \uparrow \mathrm{N}$-cadherin and vimentin & \multirow{4}{*}{ PTC } & & [54] \\
\hline miR-574-5p & & $\downarrow \mathrm{SCAI} \rightarrow \uparrow \beta$-catenin & & & [55] \\
\hline miR-625-3p & & $\uparrow$ Bcl-2, $\downarrow$ Bax, and cleaved caspase 3/9 & & & [56] \\
\hline miR-96 & & $\downarrow$ FOXO1 $\rightarrow \downarrow$ Bim & & Cell line & [57] \\
\hline Let-7a & \multirow{12}{*}{$\downarrow$} & Not known & Not known & Tissue & [58] \\
\hline miR-125a-5p & & $\uparrow$ CD147 $\rightarrow \downarrow$ glucose metabolism & PTC, FTC, MTC and ATC & \multirow{4}{*}{ Cell line and tissue } & [59] \\
\hline miR-1266 & & $\uparrow$ FGFR2 & \multirow{2}{*}{ PTC } & & [60] \\
\hline miR-141-3p & & $\uparrow Y Y 1$ & & & [61] \\
\hline miR-144 & & $\uparrow \mathrm{TGF}-\alpha$ & \multirow{2}{*}{ ATC } & & [62] \\
\hline miR-148a & & $\uparrow$ INO80 & & ATC cancer stem cells & [63] \\
\hline miR-150 & & $\uparrow R O C K 1$ & \multirow{6}{*}{ PTC } & \multirow{6}{*}{ Cell line and tissue } & [64] \\
\hline miR-195 & & $\begin{array}{c}\uparrow \mathrm{CCND} 1 \text { and FGF2 } \rightarrow \uparrow \beta \text {-catenin, } \\
\text { c-Myc, cyclin D1 and MMP-13 }\end{array}$ & & & [65] \\
\hline miR-199b-5p & & $\uparrow \mathrm{STON} 2 \rightarrow \uparrow \mathrm{N}$-cadherin and fibronectin & & & [66] \\
\hline miR-375 & & $\uparrow$ ERBB2 & & & [57] \\
\hline $\operatorname{miR}-497$ & & $\uparrow$ AKT3 & & & [67] \\
\hline miR-524-5p & & $\uparrow$ FOXE1 and ITGA3 & & & [68] \\
\hline $\operatorname{miR}-7$ & & $\uparrow \mathrm{PAK} 1$ & & & [69] \\
\hline miR-873-5p & & $\begin{array}{c}\uparrow \text { CXCL16 } \rightarrow \uparrow \text { p-p65 and p-Rel-B, } \\
\text { MMP1, MMP9 and MMP13 }\end{array}$ & & & [70] \\
\hline $\operatorname{miR}-9-5 p$ & & $\uparrow \mathrm{BRAF}$ & & & [67] \\
\hline
\end{tabular}

PTC: Papillary Thyroid Cancer; FTC: Follicular Thyroid Cancer; ATC: Anaplastic Thyroid Cancer; MTC: Medullar Thyroid Cancer; FOXN3: Forkhead Box N3; QKI5-7: Quaking protein 5-7; SCAI: Suppressor of Cancer Cell Invasion; CXCL16: C-X-C Motif Chemokine Ligand 16; SOCS1: Suppressor Protein of Cytokine Signaling 1; MMP1: Matrix Metallopeptidase 1; VHL: Von Hippel-Lindau Tumor Suppressor; RAR- $\beta$ : Retinoic Acid Receptor Beta; FOXE1: Forkhead Box E1; ITGA3: Integrin Subunit Alpha 3; HK2: Hexokinase 2; YY1: Yin Yang 1; STON2: Stonin 2; FGFR2: Fibroblast Growth Factor Receptor 2; TGF- $\alpha$ : Transforming Growth Factor Alpha; AKT3: RAC- $\gamma$ serine/threonine-protein kinase; CCND1: Cyclin D1; FGF2: Fibroblast Growth Factor; ROCK1: Rho-associated Protein Kinase 1; PAK1: p21 Activated Kinase-1; ERBB2: Erb-B2 Receptor Tyrosine Kinase 2; FOXO1: Forkhead Box O1. 


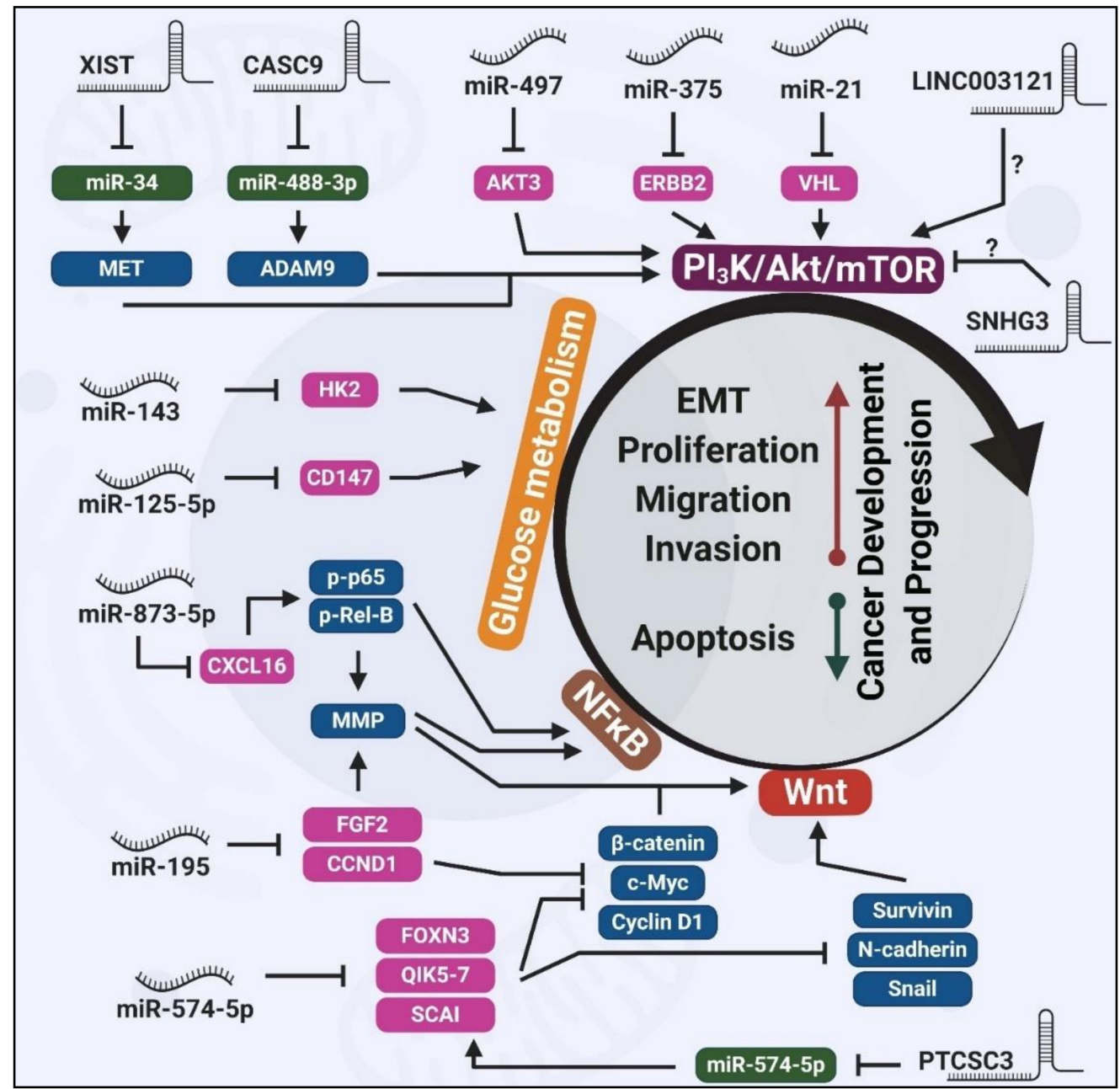

Figure 2. Schematic overview of ncRNA involvement in thyroid cancer-related signaling pathways. Key components of the $\mathrm{PI}_{3} \mathrm{~K} / \mathrm{Akt} / \mathrm{mTOR}$ pathway, such as AKT3, ERBB2 and VHL, are regulated by different miRNAs and lncRNAs in thyroid cancer. The metabolism of glucose is regulated by miR-143 and miR-125-5p. Well-known cancer-related pathways, NFkB and Wnt, are tightly regulated by miRNAs and lncRNAs in thyroid cancer. Dysregulation of these miRNAs and lncRNAs in various types of thyroid cancer eventually results in the induction of proliferation, migration and invasion, while apoptosis is suppressed. Note: Pink represents direct targets of miRNAs, green represents direct miRNA targets of lncRNAs and blue represents the indirect target of miRNA or lncRNAs.

\subsection{Wnt-Mediated Tumorigenic Effects of Dysregulated miRNAs}

Wnt signaling pathway is essential to embryonic development and tissue homeostasis. Hyperactivation of Wnt signaling is abundant in human cancer [71,72] and thyroid carcinoma is not an exception [73]. miR-574-5p is one of the most well-studied miRNAs that is linked to thyroid carcinomas, FTC and PTC in particular, via Wnt pathway. Up-regulation of miR-574-5p was reported by different groups to promote proliferation, Epithelial-Mesenchymal Transition (EMT), invasion, migration and inhibit apoptosis [55,74,75]. miR-574-5p exerts its oncogenic effects via targeting Forkhead Box N3 (FOXN3), Quaking protein 5-7 (QKI5-7), and Suppressor of Cancer Cell Invasion (SCAI) transcripts. Collectively, this results in the activation of the Wnt signaling pathway. This, in turn, up-regulates $\beta$-catenin, $\mathrm{N}$-cadherin (a mesenchymal biomarker), Snail, c-Myc, cyclin D1 and survivin proteins $[55,74,75]$, leading to downstream oncogenic phenotypes and thyroid cancer development. 
In addition, the down-regulation of miR-195, which is shown in different cancers [76-80], was reported to cause thyroid tumorigenesis in vitro and in vivo via activating Wnt pathway. Through direct targeting cyclin D1 and fibroblast growth factor 2 (FGF2) genes, miR-195 was shown to inhibit cell proliferation, migration, and invasion via down-regulating $\beta$-catenin, c-Myc, cyclin D1 and matrix metallopeptidase-13 (MMP-13) [65]. A number of Wnt signaling pathway inhibitors are being examined in clinical trials, such as frizzled receptor antagonist, Vantictumab [81]. It is conceivable that Wnt pathway blockade may neutralize the oncogenic effects of miR-574-5p or miR-195 up-regulation in thyroid cancer, leading to the suppression of cancer development or progression. This hypothesis is yet to be tested experimentally.

\section{2. $\mathrm{PI}_{3} \mathrm{~K} / \mathrm{Akt}$-Mediated Tumorigenic Effects of Dysregulated miRNAs}

$\mathrm{PI}_{3} \mathrm{~K} /$ Akt signaling is a well-established oncogenic signaling pathway in multiple human cancers [82], including thyroid carcinoma [83]. Thus far, dysregulation of several miRNAs has been reported to regulate thyroid cancer by targeting the $\mathrm{PI}_{3} \mathrm{~K} / \mathrm{Akt}$ signaling pathway. For instance, miR-21 overexpression was shown to target Von Hippel-Lindau (VHL) tumor suppressor and activate $\mathrm{PI}_{3} \mathrm{~K} /$ Akt pathway. This, in turn, resulted in an increase in the EMT markers N-cadherin and vimentin, and promote cell proliferation and invasion [54]. PTEN is another validated target of miR-21, reported in various human cancers, that plays pivotal role in the inhibition of $\mathrm{PI}_{3} \mathrm{~K} / \mathrm{Akt}$ pathway [84-86]. Thus, miR-21 up-regulation could synergistically suppress $\mathrm{PI}_{3} \mathrm{~K} / \mathrm{Akt}$ pathway via targeting VHL and PTEN transcripts. This needs to be examined experimentally. In addition to miR-21, heightened expression of miR-625-3p was reported to activate $\mathrm{PI}_{3}$ K/Akt pathway via an unknown mechanism [56]. miR-497 [67] and miR-375 [57] were demonstrated to be down-regulated in thyroid cancer and target AKT3 and ErbB2 receptor tyrosine kinase 2 (ERBB2), respectively. The latter is reported to be overexpressed in PTC clinical samples [87] and mediates the resistance to mitogen-activated protein kinase (MAPK) inhibitors in BRAF-mutant thyroid cancer cell lines [88], implying that ERBB2 could drastically affect the thyroid tumorigenesis. The AKT3 up-regulation, caused by miR-497 down-regulation, resulted in the activation of $\mathrm{PI}_{3} \mathrm{~K} / \mathrm{Akt}$ pathway that eventually promotes proliferation and invasion in thyroid cancer [67]. Although miR-375 down-regulation similarly led to augmentation of oncogenic properties in vitro and in vivo [57], it is unclear whether these effects were mediated by ERBB2, a key oncogenic protein involved in the $\mathrm{PI}_{3} \mathrm{~K}$ pathway [89]. Besides, miR-96 is another example of overexpressed ncRNA in thyroid cancer with possible involvement in $\mathrm{PI}_{3} \mathrm{~K} / \mathrm{Akt}$ pathway. miR-96 imposes its proliferative and anti-apoptotic effects via targeting Forkhead Box O1 (FOXO1), a known tumor suppressor in thyroid cancer [90] that is phosphorylated and subsequently degraded by $\mathrm{PI}_{3} \mathrm{~K} / \mathrm{Akt}$ activation [91]. In parallel with $\mathrm{PI}_{3} \mathrm{~K} / \mathrm{Akt}$, miR-96 could synergistically amplify the FOXO1-mediated oncogenic properties in thyroid cancer. However, this proposed model has not been experimentally tested.

Despite the advances in harnessing the oncogenic properties of thyroid cancer via dual administration of PI3K/Akt pathway inhibitors—palbociclib and omipalisib [92] -it is not known how dysregulated miRNAs in this context could determine the drug response.

\subsection{Glucose Metabolism-Mediated Tumorigenic Effects of Dysregulated miRNAs}

The higher activity of glycolytic pathway has been shown in thyroid cancer to impose tumorigenesis $[93,94]$. Of note, miR-143 and miR-125a-5p have been reported to affect thyroid tumorigenesis via regulating glucose metabolism $[59,95]$. Studies in vitro and in vivo demonstrated that miR-143 directly targets Hexokinase 2 (HK2) and thereby down-regulates its expression. miR-143-mediated HK2 down-regulation resulted in suppressed glycolysis and therefore, decreased proliferation and migration [95]. These support the tumor-suppressive role of miR-143; however, the expression profile of this miRNA remained to be investigated in clinical thyroid cancer samples. A more comprehensive study revealed that miR-125a-5p was down-regulated in both thyroid cancer cell lines and clinical samples. miR-125a-5p was shown to block glucose metabolism via direct targeting CD147 that eventually suppressed cell viability and migration [59]. Given the clinical significance of 
targeting glucose metabolism in cancer therapy [96,97], a more in-depth study to examine both miR-143 and miR-125a-5p may open a new avenue to control thyroid cancer via regulating glucose metabolism.

\subsection{Dysregulated miRNAs in Other Signaling Pathways}

The down-regulation of miR-873-5p was shown to increase the expression of its direct target, C-X-C Motif Chemokine Ligand 16 (CXCL16) in PTC cell lines. This resulted in an increase in phosphorylation of p65 and Rel-B, thereby leading to activation of the NFאB pathway., and consequently, up-regulation of MMP1, MMP9 and MMP13 proteins. The overall phenotypic effects of miR-873-5p down-regulation are enhanced thyroid cancer cell proliferation, migration and invasion [70], which is theoretically consistent with the lowered expression of this miRNA in PTC clinical samples.

Overexpression of miR-155 was shown by Zhang et al. in ATC aggressive cells to promote cell proliferation, invasion and migration via directly targeting suppressor of cytokine signaling 1 (SOCS1) transcripts [53]. SOCS1 is a ubiquitin ligase with the tumor-suppressive activity that is silenced in human tumors [98-100]. This protein was demonstrated to be a direct inhibitor of the catalytic activity of Janus kinase 1 (JAK1), JAK2 and tyrosine kinase 2 (TYK2), thereby suppressing the JAK/signal transducer and activator of transcription (STAT) signaling pathway [101]. Given the oncogenic nature of JAK/STAT pathway in different human cancers [102] including thyroid carcinomas [103], targeting miR-155 could inhibit the thyroid cancer development/progression via activating SOCS1 and suppressing JAK/STAT. Notwithstanding, this hypothesis has not been tested in thyroid cancer. The reduced expression of miR-30 and miR-200 in ATC tumors is another remarkable finding that can help distinguish the ATC from PTCs or FTCs. The down-regulation of miR-30 and miR-200 mediates the suppression of mesenchymal-epithelial transition (MET), while inducing EMT [104].

Although the dysregulation of dozens of miRNAs has been reported in thyroid cancer, the majority of these studies focus on specific miRNAs and do not include transcriptome-wide screening approaches. Hence, RNA-seq- and/or microarray-based methods could be utilized to show a clearer map of dysregulated miRNAs. Moreover, despite the comprehensive studies with beneficial attempts to unravel the underlying molecular pathways involved in thyroid cancer, more studies are needed to fully map the mechanisms by which miRNA dysregulation mediates thyroid cancer development and progression. These could reveal the master regulator miRNAs that control key thyroid cancer signaling pathways, which may be used in personalized medicine.

\section{IncRNAs Regulating Thyroid Carcinogenesis}

LncRNAs are a sub-class of ncRNAs > 200 nucleotides in length. LncRNAs regulate target gene expression through different mechanisms. At the transcriptional level, lncRNAs can interact with the polycomb repressive complex 2 (PRC2) and confine its access to particular genomic regions, leading to the suppression of gene expression [67]. For example, HOX transcript antisense RNA (HOTAIR) suppresses homeobox D (HOXD) expression via interacting with the catalytic subunit of PRC2, called enhancer of zeste homolog 2 (EZH2) [105,106]. Alternatively, lncRNAs have been reported to recruit DNA methyltransferases to modify chromatin conformation [107-109]. As an example, PTEN pseudogene (PTENpg1) utilizes DNA methyltransferase 3A (DNMT3a) to regulate the transcription of PTEN [110]. LncRNAs can also regulate gene expression at the post-transcriptional level by complementary sequence-specific mechanisms that affect the mRNA splicing, turnover and translation [44]. For example, metastasis- associated lung adenocarcinoma transcript 1 (MALAT1) was shown to compete with splicing regulatory proteins for binding on target mRNAs [111]; BETA-SECRETASE 1-ANTISENSE (Bace1-AS) hybridizes with Bace1 mRNA to increase its half-life [112], and long intergenic non-coding RNA p21 (lincRNA-p21) recruits translation repressors to catenin beta 1 (CTNNB1) gene to silence it [113]. The schematic of lncRNAs regulatory mechanisms is shown in Figure 1.

A series of lncRNAs have been identified to be abnormally regulated and expressed in thyroid cancer (Table 2). 
Table 2. Dysregulated lncRNAs in thyroid cancer.

\begin{tabular}{|c|c|c|c|c|c|}
\hline LncRNA & Alteration & Mechanism & $\begin{array}{c}\text { Thyroid } \\
\text { Cancer Type }\end{array}$ & Sample & Ref. \\
\hline CASC9 & \multirow{15}{*}{$\uparrow$} & $\begin{array}{c}\downarrow \mathrm{miR}-488-3 \mathrm{p} \rightarrow \uparrow \text { ADAM9 } \\
\rightarrow \uparrow \mathrm{EGFR} / \mathrm{PI}_{3} \mathrm{~K} / \mathrm{Akt} \\
\text { pathway activation. }\end{array}$ & PTC & \multirow{2}{*}{$\begin{array}{l}\text { Cell line } \\
\text { and tissue }\end{array}$} & [114] \\
\hline DLX6-AS1 & & $\begin{array}{c}\text { Negatively correlated } \\
\text { with UPF1 }\end{array}$ & Not known & & [115] \\
\hline $\begin{array}{l}\text { ENST00000539653.1 } \\
\text { (ENS-653) }\end{array}$ & & Not known & PTC & \multirow{4}{*}{ Tissue } & [116] \\
\hline \multirow{3}{*}{ H19 } & & Not known & ATC & & {$[117]$} \\
\hline & & Not known & Not known & & [58] \\
\hline & & $\downarrow \mathrm{miR}-3126-5 p \rightarrow \uparrow \mathrm{ER}-\beta$ & $\begin{array}{l}\text { PTCSCs and } \\
\text { PTC tissue }\end{array}$ & & [118] \\
\hline HCP5 & & $\begin{array}{c}\downarrow \mathrm{miR}-22-3 \mathrm{p}, \mathrm{miR}-186-5 \mathrm{p} \\
\text { and miR-216a-5p } \rightarrow \uparrow \\
\text { ST6GAL2 }\end{array}$ & FTC & \multirow{7}{*}{$\begin{array}{l}\text { Cell line } \\
\text { and tissue }\end{array}$} & [119] \\
\hline LINC00152 & & $\downarrow \mathrm{miR}-497 \rightarrow \uparrow \mathrm{BDNF}$ & \multirow{4}{*}{ PTC } & & [120] \\
\hline LINC00514 & & $\downarrow \mathrm{miR}-204-3 \mathrm{p} \rightarrow \uparrow \mathrm{CDC} 23$ & & & [121] \\
\hline LINC00941 & & $\downarrow \mathrm{CDH} 6$ & & & [122] \\
\hline MALAT1 & & No mechanism & & & [123] \\
\hline n340790 & & $\downarrow \mathrm{miR}-1254$ & Not known & & [119] \\
\hline NEAT1 & & $\downarrow$ miR-9-5p $\uparrow$ SPAG9 & ATC & & [67] \\
\hline UNC5B-AS1 & & Not known & PTC & Tissue & [124] \\
\hline XIST & & $\begin{array}{c}\downarrow \mathrm{miR}-34 \mathrm{a} \rightarrow \uparrow \mathrm{MET} \rightarrow \\
\mathrm{PI}_{3} \mathrm{~K} / \text { Akt activation }\end{array}$ & Not known & $\begin{array}{l}\text { Cell line } \\
\text { and tissue }\end{array}$ & [125] \\
\hline H19 & \multirow{7}{*}{$\downarrow$} & Not known & FTC & \multirow{2}{*}{ Tissue } & [126] \\
\hline H19 & & Not known & PTC & & [127] \\
\hline LINC003121 & & $\uparrow \mathrm{PI}_{3} \mathrm{~K}$ and $\mathrm{p}-\mathrm{Akt}$ & Not known & \multirow{5}{*}{$\begin{array}{l}\text { Cell line } \\
\text { and tissue }\end{array}$} & [128] \\
\hline PAR5 & & $\uparrow$ EZH2 $\rightarrow \downarrow$ E-cadherin & \multirow{2}{*}{ ATC } & & [129] \\
\hline \multirow{2}{*}{ PTCSC 3} & & $\uparrow$ STAT3 $\rightarrow \uparrow$ INO80 & & & [130] \\
\hline & & $\begin{array}{c}\uparrow \mathrm{miR}-574-5 \mathrm{p} \rightarrow \downarrow \mathrm{SCAI} \rightarrow \\
\uparrow \beta \text {-catenin } \rightarrow \uparrow \mathrm{Wnt} \\
\text { pathway activation }\end{array}$ & \multirow[t]{2}{*}{ PTC } & & [55] \\
\hline SNHG3 & & $\begin{array}{c}\uparrow \mathrm{PI}_{3} \mathrm{~K} / \mathrm{Akt} / \mathrm{mTOR} \\
\text { pathway }\end{array}$ & & & [131] \\
\hline
\end{tabular}

PTC: Papillary Thyroid Cancer; FTC: Follicular Thyroid Cancer; ATC: Anaplastic Thyroid Cancer; PTCSCs: Papillary Thyroid Cancer Stem Cells; SNHG3: Small Nucleolar RNA Host Gene 3; PAR5: Prader Willi/Angelman Region RNA5; CASC9: Cancer Susceptibility 9; DLX6-AS1: Distal-Less Homeobox 6-Antisense 1; NEAT1: Nuclear Paraspeckle Assembly Transcript 1; UNC5B-AS1: Unc-5 Netrin Receptor B-Antisense 1; XIST: X-inactive specific transcript; MALAT1: Metastasis Associated Lung Adenocarcinoma Transcript 1; HCP5: HLA complex P5; PTCSC3: Thyroid Carcinoma Susceptibility Candidate 3; $\mathrm{PI}_{3} \mathrm{~K}$ : Phosphatidylinositol-4,5-Bisphosphate 3-Kinase; mTOR: Mechanistic Target of Rapamycin Kinase; EZH2: Enhancer of Zeste Homolog 2; ADAM9: ADAM Metallopeptidase Domain 9; EGFR: Epidermal Growth Factor Receptor; UPF1: UPF1 RNA Helicase and ATPase; ER- $\beta$ : Estrogen Receptor Beta; SPAG9: Perm-Associated Antigen 9; BDNF: Brain-Derived Neurotrophic Factor; CDH6: Cadherin 6; STAT3: Signal Transducer And Activator of Transcription 3; ST6GAL2: alpha-2, 6-sialyltransferase 2; SCAI: Suppressor of Cancer Cell Invasion.

LncRNAs play roles in regulating diverse cellular processes [132], thereby causing cancer upon dysregulation [133]. 
The dysregulation of IncRNA H19 has been studied widely in different cancers such as bladder [134], breast $[135,136]$ and liver [137]. The dysregulation of H19 in thyroid cancer is subject of controversy since the down-regulation was reported in FTC [126] and PTC [127], while the overexpression is reported in PTC, ATC [117] and PTC/PTC stem cells (PTCSCs) [118]. Given the functional studies performed in these reports, the oncogenic nature of $\mathrm{H} 19$ in thyroid cancer is more conceivable since H19 knockdown resulted in the suppression of proliferation, migration, and invasion in ATC cells in vitro and inhibited tumorigenesis and metastasis in vivo [117]. Moreover, the depletion of H19 was shown to suppress the sphere formation ability [118], collectively suggest that H19 acts as an oncogene in thyroid cancer.

In contrast to the many studies focusing on specific lncRNAs, Pellecchia et al. performed a transcriptome-wide screening using lncRNA microarray method. Comparing the ATC tumor to the normal samples revealed that Prader Willi/Angelman Region RNA5 (PAR5) was a significant down-regulated lncRNA in tumors. Mechanistically, overexpression of PAR5 expression resulted in the down-regulation and dissociation of EZH2, leading to the relieving of E-cadherin transcription efficiency, which subsequently reduced proliferation and migration of ATC-derived cells [129]. In another unbiased study, utilizing the chromatin immunoprecipitation (ChIP)-seq method, Linc00941 was found as a highly expressed enhancer-associated lncRNA in PTC tumor samples as compared to the paired healthy tissues. Of note, Linc00941 expression was significantly higher in BRAFV600E PTC patients and correlated with extrathyroidal extension in PTC patients, suggesting that the up-regulation might be mediated by BRAFV600E. However, this hypothesis was not tested. Functionally, Linc00941 promoted the proliferation and invasion of PTC cell lines, hypothetically mediated by targeting Cadherin 6 CDH6 transcripts [122].

The up-regulation and corresponding oncogenic properties of a diverse range of lncRNAs are reported in different studies, including distal-less homeobox 6-antisense 1 (DLX6-AS1) [115], nuclear paraspeckle assembly transcript 1 (NEAT1) [67], ENST00000539653.1 (ENS-653) [116], Unc-5 netrin receptor B-antisense 1 (UNC5B-AS1) [124], LINC00514 [121], LINC00152 [120], MALAT1 [123], HLA complex P5 (HCP5) [119] and n340790 [119]. Although the exact modes of action by which these IncRNAs promote/suppress thyroid carcinomas have not been elucidated, we summarize a number of altered lncRNAs with implications in Wnt and $\mathrm{PI}_{3} \mathrm{~K} / \mathrm{Akt}$ signaling pathways (Figure 2).

\subsection{Wnt-Mediated Tumorigenic Effects of Dysregulated lncRNAs}

The putative role of lncRNAs in thyroid tumorigenesis mediated by activating the Wnt signaling pathway has been also tested. Thyroid carcinoma susceptibility candidate 3 (PTCSC3) down-regulation was observed in the clinical samples as well the cell lines resulting in elevation of miR-574-5p and subsequently down-regulation of SCAI and activation of $\beta$-catenin (Figure 2). Functionally, overexpression of PTCSC 3 inhibited the cell proliferation and migration via suppressing the Wnt pathway. Besides, PTCSC 3 suppressed the growth in vivo, indicating that PTCSC 3 acts as a tumor suppressor in thyroid cancer [55]. It is unclear whether inhibiting/overexpressing the dysregulated lncRNAs could affect the downstream targetome of thyroid cancer-related signaling pathways. For example, could PTCSC3 overexpression suppress the Wnt activity using TopFlash assay?

\section{2. $\mathrm{PI}_{3} \mathrm{~K} / \mathrm{Akt}$-Mediated Tumorigenic Effects of Dysregulated lncRNAs}

In the context of the $\mathrm{PI}_{3} \mathrm{~K} / \mathrm{Akt}$ pathway, the down-regulation of small nucleolar RNA host gene 3 (SNHG3) was reported to promote growth and invasiveness in vitro and in vivo via activating $\mathrm{PI}_{3} \mathrm{~K} / \mathrm{Akt} / \mathrm{mechanistic}$ target of rapamycin kinase (mTOR) pathway [131]. However, the mechanism by which such phenotype was observed has not been elucidated. Cancer susceptibility 9 (CASC9) is another example of a dysregulated ncRNA in thyroid cancer. The up-regulation of this IncRNA was reported in PTC patient tissues and cell lines and mechanistically was shown to sponge miR-488-3p to rescue ADAM metallopeptidase domain 9 (ADAM9) oncogene. This consequently resulted in promoting 
the proliferative, migrative, and invasive abilities of thyroid cancer cells in vitro, and augmenting the tumorigenesis in vivo via activating epidermal growth factor receptor (EGFR)/ $\mathrm{PI}_{3} \mathrm{~K} / \mathrm{Akt}$ pathway [114].

Similarly, the up-regulation of X-inactive specific transcript (XIST) in thyroid cancer was demonstrated to activate the $\mathrm{PI}_{3} \mathrm{~K} / \mathrm{Akt}$ pathway via sponging miR-34a and the subsequent rescue of MET, a well-known oncogene in thyroid cancer. The functional experiments properly proved the oncogenic role of XIST, where its silencing suppressed the proliferation and tumor growth in vitro and in vivo [125].

LINC003121 is an example of down-regulated lncRNA in thyroid cancer. Although the mechanistic evaluations were not performed, the lower expression of LINC003121 was shown to increase $\mathrm{PI}_{3} \mathrm{~K}$ and p-Akt expression, leading to increased cell proliferation and invasion in vitro, and promoting tumorigenicity in thyroid cancer xenograft models in nude mice [128]. Together with reviewed miRNAs, $\mathrm{PI}_{3} \mathrm{~K} / \mathrm{Akt}$ pathway plays a pivotal role in thyroid development and progression upstream of a myriad of ncRNAs (Figure 2).

Taken together, recent evidence highlights the molecular and functional relevance of different IncRNAs in thyroid cancer, especially in the context of $\mathrm{PI}_{3} \mathrm{~K} / \mathrm{Akt}$ and Wnt signaling pathways. However, it remained to know how and to what extend the alterations in lncRNAs could influence the Wnt and/or $\mathrm{PI}_{3} \mathrm{~K}$-mediated therapy. Besides, high throughput methods, such as RNA-seq or ChIP-seq and microarray, have not been utilized to uncover the dysregulated lncRNAs in thyroid cancer patients in a transcriptome-wide manner.

\section{4. circRNAs Regulating Thyroid Carcinogenesis}

circRNAs, the stably expressed ncRNAs in different cell types with special annular structures, play fundamental regulatory roles in the physiological processes of the cell and have implications in human diseases such as cancer. Mechanistically, circRNAs impose their downstream effects via sponging miRNAs or interacting with proteins [138-140] (Figure 1). A few of oncogenic circRNAs have been reported to drive thyroid cancer (Table 3).

Table 3. Dysregulated circRNAs in thyroid cancer.

\begin{tabular}{cccccc}
\hline circRNA & Alteration & Mechanism & Sample & $\begin{array}{c}\text { Thyroid } \\
\text { Cancer Type }\end{array}$ & Ref. \\
\hline circ_0008274 & $\uparrow$ & $\begin{array}{c}\downarrow \text { AMPK/mTOR } \\
\text { signaling pathway }\end{array}$ & Cell line and tissue & PTC & {$[141]$} \\
\hline circEIF6 & $\uparrow$ & $\begin{array}{c}\downarrow \text { miR-144-3p } \rightarrow \uparrow \\
\text { TGF- } \alpha\end{array}$ & Cell line and tissue & PTC \& ATC & {$[142]$} \\
\hline circFOXM1 & $\uparrow$ & $\begin{array}{c}\downarrow \text { miR-1179 } \rightarrow \uparrow \\
\text { HMGB1 }\end{array}$ & Cell line and tissue & PTC & {$[143]$} \\
\hline
\end{tabular}

PTC: Papillary Thyroid Cancer; ATC: Anaplastic Thyroid Cancer; circFOXM1: Circular Forkhead Box Protein M1; circEIF6: circular Eukaryotic Translation Initiation Factor 6; HMGB1: High Mobility Group Box Protein 1; AMPK: 5' AMP-activated Protein Kinase; mTOR: Mammalian Target of Rapamycin (mTOR); TGF- $\alpha$ : Transforming Growth Factor Alpha.

For instance, the up-regulation of circular forkhead box protein M1 (circFOXM1) was reported in PTC tissues, as well as ATC and PTC cell lines [143]. With no effect on the linear FOXM1 transcript, circFOXM1 was demonstrated to modulate cancer progression through sponging miR-1179 and rescuing high mobility group box protein 1 (HMGB1) expression, which eventually promotes tumor growth of PTC in vitro and in vivo [143]. Likewise, the up-regulation of circ_0008274 has been reported in PTC tissues and cell lines. High circ_0008274 expression has been associated with more advanced thyroid cancer TNM staging and lymph node metastases. The in vitro studies revealed that this circRNA promoted cell proliferation and invasion. circ_0008274 imposes its effect via the activation of the mammalian target of rapamycin (mTOR) signaling pathway (increasing p-mTOR) and the inhibition of the 5' AMP-activated protein kinase (AMPK) (reducing p-AMPK) [141]. Given the known 
negative regulatory effect of AMPK on mTOR protein [144], it is conceivable that circ_0008274 activates mTOR pathway via inhibiting AMPK protein, leading to thyroid cancer development and progression. However, this notion remained to be tested in depth in thyroid cancer cell lines.

Collectively, circRNAs have been shown to be deregulated and promote thyroid cancer mainly through sponging miRNAs. More studies are needed, particularly in ATC and metastatic thyroid cancers, to develop deeper insights on circRNAs roles in thyroid cancer initiation and promotion.

\section{5. ncRNAs May Regulate the Biology of Thyroid Tumor Microenvironment}

The tumor microenvironment is composed of a variety of tumor-associated immune cells as well as growth factors, cytokines, and chemokines. Changes in the tumor microenvironment that occurs during cancer progression could induce various biological processes like angiogenesis, proliferation, invasion and metastasis, immune tolerance and alter the response to therapeutic agents $[145,146]$. $\mathrm{B}$ cells, T cells, mast cells, dendritic cells and macrophages are the main immune cells accumulated in the tumor microenvironment, where machrophages are characterized by plasticity and diversity and play an important role in the immune response [147]. In response to hypoxia, tumor-associated macrophages produce WNT7b, which in turn attributes to up-regulation of vascular endothelial growth factor (VEGF) by adjacent vascular endothelial cells in the tumor microenvironment. This eventually results in the elevated angiogenesis and promotion of tumor growth $[148,149]$. Of note, the secretion of diverse chemokines and cytokines recruits the regulatory $\mathrm{T}$ lymphocytes that result in the inhibition of effector T cells [150]. Although there is lack of conclusive evidence about the roles of ncRNAs in regulating the microenvironment-associated cells/components in thyroid cancer, here we review the current data and propose the potential ncRNA-related mechanisms.

NEAT1, an up-regulated IncRNA in thyroid cancer, has been reported to induce tumor-associated macrophages via sponging miR-214 and inducing the $\beta$-catenin/Wnt signaling pathway [151]. This further highlights the therapeutic potential of NEAT1 as a potential target for thyroid cancer therapy [152]. Another highly-expressed lncRNA in thyroid cancer, MALAT1, can activate angiogenesis via increasing fibroblast growth factor 2 (FGF2) expression in tumor-associated macrophages [153]. Another up-regulated lncRNA, PTCSC3, may also regulate the thyroid cancer tumor microenvironment via activating the Wnt signaling pathway [55].The up-regulation of miR-574-5p and miR-195 has been discussed in Section 2.1 to induce proliferation, EMT, invasion and migration via activating the Wnt pathway in thyroid cancer. miR-574-5p and/or miR-195 overexpression could induce the chemokines/cytokines and activate the tumor-associated immune cells. This hypothesis remained to be tested to assess the potential of these miRNAs in modulating the thyroid tumor microenvironment.

\section{6. ncRNAs are Novel Candidates for Early Detection of Thyroid Cancer}

In poorly differentiated, medullary, and anaplastic thyroid carcinomas [154], early detection of cancer is key to maximizing the chance of successful treatment and prolonging patient survival. This is achieved by systematic screening and recognizing the warning signs [155]. For thyroid cancer, the current standard of care is to perform neck ultrasonography together with FNA cytology, which are determinants to discriminate benign and malignant thyroid nodules [156]. However, $10-40 \%$ of thyroid nodule FNA cytology results are indeterminate, resulting in a repeat FNA several months later $[157,158]$. In indeterminate thyroid FNA cytology, the estimated incidence of malignancy ranges between 10 and 75\% [159]. Furthermore, it is not possible to distinguish the benign follicular adenoma (FA) from the malignant FTC via FNA cytology unlike other forms of thyroid cancers. Hence, the diagnosis of malignancy in this group can only be made post-surgery via histology that demonstrates the presence of capsular or vascular invasion. This difficulty in making a definite diagnosis for cytologically-indeterminate FNA usually results in delayed definitive treatment and management. Treatment for repeatedly indeterminate cases usually takes the form of a diagnostic hemi-thyroidectomy, or a two-stage thyroidectomy for patients with thyroid cancer on diagnostic histology. Furthermore, the majority of patients (76-81\%) with indeterminate cytology have benign 
thyroid nodules and thus were subjected to unnecessary diagnostic thyroid surgeries [160]. As such, there is a critical need for clinicians to improve the ability to predict the risk of thyroid cancer in thyroid nodules.

As reviewed in the introduction section, molecular tests for oncogene mutations such as BRAF, NRAS, KRAS, HRAS, Pax8-PPARG, re-arrangement of RET and TERT have been used to improve benign/malignant differentiation [6,161]. However, they have not increased the specificity of such diagnostic methods [162,163]. Moreover, the performance of these kits may also differ in different populations due to the different prevalence of the genetic alterations of interests. For example, while $\mathrm{BRAF}{ }^{\mathrm{V} 600 \mathrm{E}}$ is present in $38-58 \%$ of thyroid cancers in patients of European ancestry, the prevalence across East Asia can range from 80\% in Korea, 62\% in China, and 53\% in India [164-169]. These suggest that more molecular tools are needed, especially for the timely diagnosis of advanced thyroid cancers. Here, we focus on the significance of diagnostic ncRNAs in thyroid cancer (Table 4).

Table 4. Diagnostic ncRNAs in thyroid cancer.

\begin{tabular}{|c|c|c|c|c|c|}
\hline ncRNA & ncRNA Type & Source & Finding & $\begin{array}{l}\text { Thyroid } \\
\text { Samples }\end{array}$ & Ref. \\
\hline $\begin{array}{c}\text { miR-138-1-3p } \\
\text { miR-139-5p } \\
\text { miR-146b-5p } \\
\text { miR-155miR-204-5p } \\
\text { miR-222-3pmiR-29b-1-5p } \\
\text { miR-31-5p } \\
\text { miR-375 } \\
\text { miR-551b-3p }\end{array}$ & \multirow{8}{*}{ miRNA } & \multirow[t]{2}{*}{ FNA } & $\begin{array}{l}\text { miRNA testing, recently } \\
\text { commercialized as } \\
\text { ThyraMIR, identified } \\
64 \% \text { of malignant cases } \\
\text { and } 98 \% \text { of benign } \\
\text { cases correctly. }\end{array}$ & Not known & [170] \\
\hline $\mathrm{miR}-146 \mathrm{~b}$ & & & $\begin{array}{l}\text { Higher expression in } \\
\text { PTC FNA samples }\end{array}$ & PTC & [171] \\
\hline $\begin{array}{c}\mathrm{miR}-132-3 p \\
\text { miR-146a-5pmiR-17-5p } \\
\text { miR-183-3p } \\
\text { miR-222-3p } \\
\text { miR-451a }\end{array}$ & & \multirow{6}{*}{ Serum } & $\begin{array}{l}\text { miR-222-3p and } \\
\text { miR-17-5p can accurately } \\
\text { discriminate MTC from } \\
\text { the benign nodule and } \\
\text { healthy control groups }\end{array}$ & $\begin{array}{l}\text { PTC, MTC, } \\
\text { benign nodules } \\
\text { and controls }\end{array}$ & [172] \\
\hline $\begin{array}{l}\text { miR-146a-5p } \\
\text { miR-221-3p } \\
\text { miR-222-3p }\end{array}$ & & & $\begin{array}{c}\text { High pre-surgical } \\
\text { expressionLow } \\
\text { post-surgical expression }\end{array}$ & \multirow{5}{*}{ PTC } & [173] \\
\hline $\begin{array}{l}\text { miR-146b } \\
\text { miR-21 } \\
\text { miR-221 } \\
\text { miR-222 }\end{array}$ & & & $\begin{array}{l}\text { Higher expression in } \\
\text { PTM serum samples }\end{array}$ & & [174] \\
\hline $\begin{array}{l}\text { miR-146a-5p } \\
\text { miR-199b-3p }\end{array}$ & & & $\begin{array}{l}\text { Lower expression in PTC } \\
\text { serum as compared to } \\
\text { benign serum samples }\end{array}$ & & \multirow[t]{2}{*}{ [175] } \\
\hline let-7b-5pmiR-10a-5p & & & $\begin{array}{l}\text { Higher expression in } \\
\text { PTC serum as compared } \\
\text { to benign serum samples }\end{array}$ & & \\
\hline miR-423-5p & & & $\begin{array}{l}\text { Higher expression in } \\
\text { PTC serum samples }\end{array}$ & & [176] \\
\hline let-7a & & Tissue & $\begin{array}{l}\text { Lower expression in } \\
\text { thyroid tumor samples }\end{array}$ & Not known & [58] \\
\hline H19 & \multirow{5}{*}{$\operatorname{lncRNA}$} & & $\begin{array}{l}\text { Higher expression in } \\
\text { thyroid tumor samples }\end{array}$ & & \\
\hline H19 & & & $\begin{array}{l}\text { Lower expression in } \\
\text { thyroid tumor samples } \\
\text { as compared to } \\
\text { benign samples }\end{array}$ & PTC & [127] \\
\hline MALAT1 & & & \multirow{3}{*}{$\begin{array}{l}\text { Higher expression in } \\
\text { thyroid tumor samples }\end{array}$} & & [123] \\
\hline n340790 & & & & Not known & [119] \\
\hline UNC5B-AS1 & & & & PTC & [124] \\
\hline
\end{tabular}

PTC: Papillary Thyroid Cancer; MTC: Medullar Thyroid Cancer; UNC5B-AS1: Unc-5 Netrin Receptor B-Antisense RNA 1; MALAT1: Metastasis Associated Lung Adenocarcinoma Transcript 1; FNA: Fine Needle Aspiration. 
ncRNAs have tremendous potential as diagnostic biomarkers as they are found to be stable and detectable in body fluids [177-179]. For instance, miR-10b-5p, miR-195-5p, miR-132-3p, miR-20a3p, miR-185-5p, and miR-296-5p are reported to be significantly overexpressed in gastric cancer patients' sera [180]. Commercially, a lncRNA named prostate cancer-associated 3 (PCA3) has been approved by the US Food and Drug Administration as a urine biomarker for prostate cancer [181].

The diagnostic significance of miR-222, miR-146a-5p and miR-146b has been shown by different studies. Zhang et al. studied the serum level of miR-222-3p, miR-17-5p, miR-451a, miR-146a-5p, miR-132-3p and miR-183-3p in PTC, MTC, benign nodule and control groups. The results revealed that the serum levels of miR-222-3p, miR-17-5p, and miR-451a were markedly increased, while miR-146a-5p, miR-132-3p, and miR-183-3p were significantly decreased in the PTC and benign nodule groups compared with the control group. There was no difference in the miRNA expression profile between the PTC and the benign nodule group. Nevertheless, the serum levels of miR-222-3p and miR-17-5p were significantly increased in the MTC group than the benign nodule and control groups. Therefore, they concluded that miR-222-3p and miR-17-5p can accurately discriminate MTC from the benign nodule group and healthy controls [172]. Rosignolo et al. studied the serum level of miR-146a-5p, miR-221-3p and miR-222-3p before and 30 days after surgery in PTC patients. The pre-surgical high expression of these miRNAs with a significant post-surgical down-regulation supported the diagnostic significance of miR-146a-5p, miR-221-3p and miR-222-3p [173]. Moreover, the heightened serum level of miR-222, miR-221, miR-146b and miR-21 was detected in the PTC tumors with $<10 \mathrm{~mm}$ diameter as compared to benign nodules [174]. The importance of miR-146b was supported by another study that showed the escalated expression of this miRNA in FNA biopsy samples of PTC samples [171]. Graham et al. measured the expression level of miRNAs in the serum of PTC samples versus the benign nodule group. The results revealed that miR-146a-5p and miR-199b-3p were highly expressed in the PTC group, whereas let7b-5p and miR-10a-5p were down-regulated [175]. These various studies on the clinical significance of miRNAs have resulted in the advent of a commercial diagnostic product in thyroid cancer. ThyraMIR ${ }^{\circledR}$ miRNA classifier product is developed to be used in combination with the conventional molecular diagnostic platform as a new thyroid cancer diagnostic tool, with promising outcomes showing $89 \%$ sensitivity and $85 \%$ specificity [170]. This kit is expected to reduce $85 \%$ of unnecessary surgeries of benign thyroid nodules [161,182-184]. The miRNAs utilized in this classifier are miR-29b-1-5p, miR-31-5p, miR-138-1-3p, miR-139-5p, miR-146b-5p, miR-155, miR-204-5p, miR-222-3p, miR-375 and miR-551b-3p.

Although the diagnostic values of miRNAs have been widely studied in the serum, the diagnostic significance of lncRNAs is dominantly studied in tissues. This may be because the stability of lncRNA levels is the lowest among several different RNA species [185]. A nonrandomized, retrospective study examining PTC patients and benign thyroid nodes revealed that lower H19 expression levels could distinguish PTC from benign with area under the curve (AUC) of the receiver operating characteristic (ROC) curve of 0.813 [127]. Liu et al. also studied the diagnostic significance of H19 together with let-7a in thyroid cancer patients showing that these ncRNAs could discriminate the thyroid cancer tumors against the healthy samples with AUC of 0.801 and 0.116 for $\mathrm{H} 19$ and let-7a, respectively [58]. The higher expression of UNC5B-AS1, MATAL1 and n340790 was shown to distinguish the tumor and normal samples with AUC values of $0.932,0.632$ and 0.845 , respectively $[119,123,124]$. With the increasing identification of diagnostic circulating lncRNAs in different cancers [186-190], we expect to see the utilization of circulating lncRNAs to optimize diagnostic accuracy of thyroid nodules in the future. Collectively, ncRNAs could be clinically relevant biomarkers for thyroid cancer diagnosis (Figure 3). 


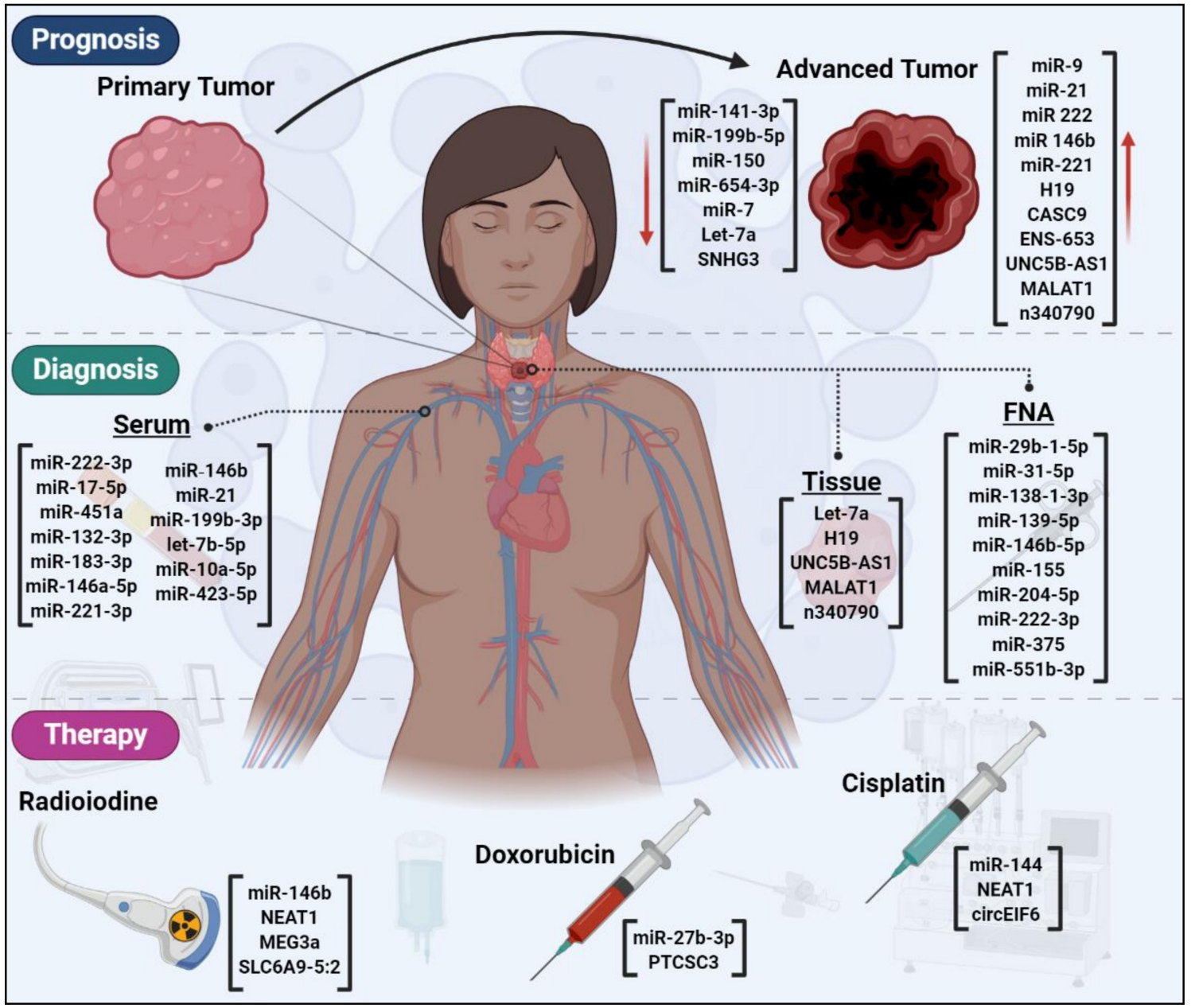

Figure 3. The diagnostic, prognostic and therapeutic significance of dysregulated ncRNAs in thyroid cancer. A variety of ncRNAs are dysregulated during primary to advanced tumor progression. These ncRNAs could have implications for the prognosis of thyroid cancer patients. The expression levels of ncRNAs could distinguish normal from tumor thyroid cells, therefore, acting as diagnostic biomarkers. Several ncRNAs may determine the response/resistance to the routine thyroid cancer treatment options of radioiodine and/or chemotherapy. FNA: fine needle aspiration.

Other than the ncRNAs utilized in the current commercial kit, other potential ncRNAs such as miR-146a-5p and H19 could be evaluated in clinical validation studies as diagnostic biomarkers. Although no circRNA has been reported to convey diagnostic significance in thyroid cancer, these ncRNAs have tremendous potential as diagnostic biomarkers due to the high stability of their circular structure and accumulation in exosomes. These characteristics result in the stable secretion of circRNAs in peripheral body fluids such as plasma and saliva, where they can be detected for early diagnosis of cancer [170,191-193].

\section{7. ncRNAs as Prognostic Factors for Thyroid Cancer}

ncRNAs have recently shown a massive capability as prognostic factors in human cancers [194,195]. For instance, the reduced expression of let-7 was shown to be associated with shortened postoperative survival of lung cancer patients [196]; and tumor suppressor candidate 7 (TUSC7) is a prognostic lncRNA that is inversely associated with aggressive stages and shorter survival of gastric cancer patients has been reported [197].

Thus far, BRAF ${ }^{\mathrm{V} 600 \mathrm{E}}$ and TERT [13]/p53 [198] mutations are the main molecular prognostic biomarkers [199] used along with clinicopathological factors such as age, extra-thyroid tumor spread, 
lymph node and distant metastases and increasing tumor size in thyroid cancer [200]. Nonetheless, nearly $30 \%$ of thyroid cancer patients may face over- or undertreatment in a condition based on BRAF status alone [200]. Moreover, the impact of BRAF status on the risk of recurrence in the very low-risk patients appears to be small [13]. This suggests that more molecular biomarkers are needed to determine the prognosis of thyroid cancer patients. In this section, we review the recent advances in prognostic ncRNAs in thyroid cancer, that are listed in Table 5.

Table 5. Prognostic ncRNAs in thyroid cancer.

\begin{tabular}{|c|c|c|c|c|}
\hline ncRNA & ncRNA Type & Prognostic Significance & $\begin{array}{c}\text { Thyroid } \\
\text { Cancer Type }\end{array}$ & Ref. \\
\hline Let-7a & \multirow{10}{*}{ miRNA } & $\begin{array}{l}\text { Negative correlation with higher TNM stages } \\
\text { lymph node metastasis and lower 5-year survival }\end{array}$ & Not known & [58] \\
\hline miR-141-3p & & $\begin{array}{c}\text { Negative association with TNM stage and lymph } \\
\text { node metastasis }\end{array}$ & \multirow{11}{*}{ PTC } & [61] \\
\hline $\begin{array}{l}\text { miR-146b } \\
\text { miR-21 } \\
\text { miR-222 }\end{array}$ & & Poor prognosis & & {$[174]$} \\
\hline miR-150 & & $\begin{array}{l}\text { Negative association with TNM stage and lymph } \\
\text { node metastasis }\end{array}$ & & [64] \\
\hline miR-199b-5p & & Negative association with stage & & [66] \\
\hline miR-21 & & Poor prognosis & & [54] \\
\hline $\begin{array}{c}\text { miR-21 } \\
\text { miR-9 }\end{array}$ & & $\begin{array}{l}\text { Independent prognostic factors of } \\
\text { PTC recurrence }\end{array}$ & & [201] \\
\hline miR-221 & & $\begin{array}{l}\text { Independent prognostic factors of } \\
\text { PTC recurrence }\end{array}$ & & [202] \\
\hline miR-654-3p & & $\begin{array}{l}\text { Down-regulation upon a long-term PTC } \\
\text { progression in BRAF }{ }^{\mathrm{V} 600 \mathrm{E}} \text {-transgenic mice }\end{array}$ & & [203] \\
\hline miR-7 & & Negative association with stage & & [69] \\
\hline CASC9 & \multirow{10}{*}{$\operatorname{lncRNA}$} & $\begin{array}{l}\text { Positive association with large tumor size, } \\
\text { advanced stage, or lymph node metastasis. }\end{array}$ & & [114] \\
\hline $\begin{array}{l}\text { ENST00000539653.1 } \\
\quad \text { (ENS-653) }\end{array}$ & & $\begin{array}{c}\text { Positive association with larger tumor size, more } \\
\text { advanced clinical stage and poorer } \\
\text { disease-free survival }\end{array}$ & & [116] \\
\hline \multirow{4}{*}{ H19 } & & $\begin{array}{l}\text { Positive correlation with higher TNM stages } \\
\text { lymph node metastasis and lower 5-year survival }\end{array}$ & Not known & [58] \\
\hline & & Positive correlation with poor overall survival & $\begin{array}{l}\text { PTCSCs and } \\
\text { PTC tissue }\end{array}$ & [118] \\
\hline & & $\begin{array}{c}\text { Negative correlation with extrathyroid extension, } \\
\text { tumor size, histological aggressive type, } \\
\text { pathological lateral node metastasis and poorer } \\
\text { disease-free survivalIndependent risk factor for } \\
\text { extrathyroidal extension and lymph } \\
\text { node metastasis. }\end{array}$ & PTC & [127] \\
\hline & & $\begin{array}{l}\text { Negative association with tumor size, distant } \\
\text { metastasis and vascular invasion }\end{array}$ & FTC & [126] \\
\hline MALAT1 & & $\begin{array}{l}\text { Positive correlation with tumor size and lymph } \\
\text { node metastases }\end{array}$ & PTC & [123] \\
\hline n340790 & & $\begin{array}{l}\text { Positive correlation with primary } \\
\text { clinicopathological characteristics (good } \\
\text { prognostic factor) }\end{array}$ & Not known & [119] \\
\hline SNHG3 & & $\begin{array}{l}\text { Negative association with stage and } \\
\text { poor prognosis }\end{array}$ & \multirow{2}{*}{ PTC } & [131] \\
\hline UNC5B-AS1 & & $\begin{array}{l}\text { Positive correlation with lymph node metastasis, } \\
\text { tumor size and histological type }\end{array}$ & & [124] \\
\hline
\end{tabular}

PTC: Papillary Thyroid Cancer; FTC: Follicular Thyroid Cancer; ATC: Anaplastic Thyroid Cancer; PTCSCs: Papillary Thyroid Cancer Stem Cells; SNHG3: Small Nucleolar RNA Host Gene 3; CASC9: Cancer Susceptibility 9; PTCSC3: Thyroid Carcinoma Susceptibility Candidate 3; UNC5B-AS1: Unc-5 Netrin Receptor B-Antisense RNA 1; MALAT1: Metastasis Associated Lung Adenocarcinoma Transcript 1. 
The overexpression and oncogenic actions of miR-21 have been widely reported in thyroid cancer [54,204-206], suggesting that this miRNA could be a potential diagnostic factor for early detection of thyroid cancer. Beyond that, the association between miR-21 with the clinicopathological characteristics of thyroid cancer uncovered its capability to be used as a prognostic factor. The survival analysis by Zang et al. revealed that the higher expression of miR-21 can predict poor prognosis of PTC patients [54]. In another study, the multivariate survival analysis of patients for at least 120 months after surgery showed that miR-9 and miR-21 were significant independent prognostic factors for recurrence of PTC patients [201]. Zhang et al. studied miR-21 together with miR-221, miR-222 and miR-146b and depicted that all these miRNAs, except for miR-221, were highly expressed in poor-prognosis PTC patients group [174]. Comparing the expression level of miR-21, miR-222, miR-9, miR-10b, miR-146b, miR-31, miR-220 and miR-221 in recurrent vs. non-recurrent groups in another study showed that although all the miRNAs were dysregulated, only miR-221 overexpression was the independent prognostic factor of PTC recurrence [202]. The different outcomes among these studies could be due to the type of statistical tests used, e.g., multivariate vs. univariate Cox survival analysis. A deeper epidemiological analysis encompassing more dysregulated miRNAs, all the clinicopathological features and controlling for potential confounder parameters in a larger cohort size could better assess the utility of these miRNAs as prognostic markers.

miR-141-3p and miR-150 were separately demonstrated by different studies to be inversely associated with TNM stage and lymph node metastasis in PTC patients [61,64]. Similarly, the inverse association between miR-199b-5p or miR-7 and TNM stage was shown in PTC patients [66,69]. In another study, Geraldo et al. performed a prognosis study using the BRAF ${ }^{\mathrm{V} 600 \mathrm{E}}$-mutant PTC progression model in mice. The results interestingly showed that miR-654-3p levels underwent a significant decrease with long-term PTC progression in mice and negatively correlated with EMT. They further reported the down-regulation of miR-654-3p in PTC cell lines with the subsequent effect on increasing proliferation and migration. This suggests that not only this miRNA undergoes down-regulation in PTC development, but it also continues to be suppressed to progress cancer. Nonetheless, the epidemiological study is required to prove it as a prognostic factor in thyroid cancer [69].

With regard to the prognostic values of IncRNAs in thyroid cancer, several lncRNAs have been investigated. The decreased expression of small nucleolar RNA host gene 3 (SNHG3) was shown to correlate with the higher TNM stages and poorer prognosis of PTC patients [131]. On the contrary, CASC9, ENS-653, MALAT1 and UNC5B-AS1 associated positively with the advanced clinicopathological characteristics including large tumor size, advanced stage, or lymph node metastasis in PTC patients [114,116,123,124]. IncRNA H19 has been widely studied in different thyroid cancer cohorts that showed controversial prognostic results. In PTC, H19 was shown to be inversely associated with tumor size, pathological lateral node metastasis, extrathyroid extension, histological aggressive type and poorer disease-free survival [127]. The multivariate analysis of this retrospective, non-randomised study including 89 patients with benign thyroid nodes and 410 patients with PTC confirmed that $\mathrm{H} 19$ could be an independent risk factor for the extrathyroidal extension and lymph node metastasis [127]. Li et al. reported that higher H19 expression correlated with the poorer overall survival of PTC patients [118]. Similarly, Liu et al. studied thyroid cancer patients and showed that H19 positively correlated with higher TNM stages, lymph node metastasis and lower 5-year survival rate. Controlling for another ncRNA surveyed in this study, the higher H19 and lower let-7a along with tumor size, stage and lymph node metastasis were confirmed as the independent prognostic factors of thyroid cancer [58]. In FTC, H19 was revealed as the prognostic factor negatively associated with tumor size, distant metastasis and vascular invasion. However, the multivariate regression demonstrated that only age, primary tumor size $\geq 4 \mathrm{~cm}$ and vascular invasion were the significant prognostic factors of survival [126].

Taken together, the prognostic significance of ncRNAs has been shown in thyroid cancer (Figure 3). Notwithstanding, very little is known about the prognostic ncRNAs in more advanced thyroid cancers 
of MTC and ATC that show worse prognosis as compared to PTC and FTC. This indicates that the dysregulated ncRNAs could be studied epidemiologically in MTC/ATC cohorts.

\section{8. ncRNAs Could Affect Thyroid Cancer Therapy}

Upon thyroid cancer diagnosis, surgical excision of tumors is performed [13]. Patients with more advanced, differentiated thyroid cancers and a higher risk of recurrent or persistent disease undergo adjuvant RAI therapy. The molecular basis of this adjuvant therapy is the uptake of RAI via the plasma membrane sodium iodide symporter (NIS). NIS mediates the influx of RAI via transporting two $\mathrm{Na}^{+}$ions and one $\mathrm{I}^{-}$ion into the cytosol. RAI is then concentrated into the thyroid cells by iodine-metabolizing machinery. This eventually increases the efficiency of RAI therapy and improves the prognosis of thyroid cancer patients.

Notwithstanding, about $25-50 \%$ of locally advanced or metastatic thyroid cancers become refractory to RAI therapy. This leads to a poorer outcome with 5-year survival of $<50 \%$ and 10 -year survival of $<10 \%[207,208]$. RAI refractory response occurs through a complex de-differentiation process that leads to a diminished or a loss of NIS expression and/or correct localization. These prevent the cytoplasmic influx of RAI in thyroid cells, thereby causing adjuvant therapy resistance [209]. There are multiple mechanisms by which RAI resistance happens. Dysregulation of the MAPK signaling pathway is a well-studied mechanism that represses NIS protein expression. Thyroid cancer cells harboring $\mathrm{BRAF}^{\mathrm{V} 600 \mathrm{E}}$ mutations exhibit robust activation of MAPK signaling, associated with a de-differentiated state [209]. BRAF ${ }^{\mathrm{V} 600 \mathrm{E}}$-induced MAPK-independent repression of NIS has also been reported, where BRAF ${ }^{\mathrm{V} 600 \mathrm{E}}$ induces Transforming Growth Factor $\beta$ (TGF- $\beta$ ) secretion. This resulted in the repression of NIS and elevated oncogenic properties in PTC cells [210]. The mechanistic role of $\mathrm{PI}_{3} \mathrm{~K}$ and notch signaling pathways have also been demonstrated in RAI resistance [211]. Although the diversity of underlying mechanisms delineates the complexity and difficulty of the restoration of RAI sensitivity in thyroid cancer patients, different approaches have been implemented to overcome this clinical obstacle. Treatment of RAI-refractory thyroid cancer patients with retinoic acid [212], epigenetic transcriptional restoration of NIS expression via histone deacetylase inhibitors (HDACi) [213], or peroxisome proliferator-activated receptor (PPAR)- $\gamma$ agonist [214] have shown sub-optimal re-differentiation outcomes for the patients.

Among various tested measures, ncRNAs have emerged as potential modulators of NIS restoration. Inhibition of miR-21, an upregulated miRNA in thyroid cancer, resulted in up-regulation of NIS expression, although the detailed mechanisms remain unknown [204]. In addition, miR-146b was reported to be highly up-regulated in dedifferentiated thyroid cancer cells, resulting in the repression of NIS via direct targeting of the NIS mRNA $[215,216]$. NIS expression can also be regulated by let7f-5p in PTC and FTC cells [217]. These findings highlight the potential clinical significance of inhibiting NIS-targeting miRNAs with respect to the re-differentiation and restoration of RAI sensitivity in RAI-refractory thyroid cancer patients. Additionally, transcriptome-wide approaches will be critical to identify the dysregulated IncRNAs and circRNAs in de-differentiated thyroid cancer cases, providing previously uncharacterized targets forpotential ncRNA-based strategies for the restoration of NIS expression. Given the known regulatory effects of miR-375, miR-497, CASC9 and XIST on the $\mathrm{PI}_{3} \mathrm{~K} / \mathrm{Akt}$ signaling pathway (Figure 2) — that is involved in NIS repression—in-depth studies could unravel their potential roles in the redifferentiation process.

Currently, patients with RAI-refractory differentiated thyroid cancer undergo systemic therapy, including targeted therapy and chemotherapy [12]. The chemotherapy drugs commonly used to treat thyroid cancer, in particular, the aggressive medullary and anaplastic thyroid malignancies are dacarbazine, vincristine, cyclophosphamide, doxorubicin, streptozocin, fluorouracil, paclitaxel, docetaxel and carboplatin [218-222]. However, chemotherapy is rarely used for thyroid cancer treatment, except for ATC patients. Doxorubicin was the only chemotherapy approved for the treatment of thyroid cancer patients. Nevertheless, it yielded a complete or partial response rate of $<40 \%$ with limited durability [223]. Thus far, 2 multi-targeted tyrosine kinase inhibitors, sorafenib and 
lenvatinib, have been FDA-approved for the treatment of locally advanced or metastatic progressive RAI-refractory differentiated thyroid cancer. Both had been shown to improve progression-free survival but not overall survival [224-226]. For progressive metastatic MTC, 2 multi-targeted tyrosine kinase inhibitors, vandetanib and cabozantinib showed to improve progression-free survival and have been FDA-approved $[227,228]$. In metastatic BRAF ${ }^{\mathrm{V} 600 \mathrm{E}}$-mutant ATC, combined targeted therapy with dabrafenib and trametinib has been shown to improve progression-free survival and is FDA-approved for this indication [229]. Mutation-selective kinase inhibitor such as RET-inhibitor selpercatinib is FDA-approved for the treatment of metastatic RET-mutant MTC or RET-fusion mutant differentiated thyroid cancers with phase II clinical trial showing an overall response rate of $70 \%$. Another mutation-selective kinase inhibitor that has been FDA-approved is the TRK inhibitor (larotrectinib or entrectinib) that can be used in metastatic thyroid cancers with NTRK-fusion mutation [230,231].

Serum thyroglobulin (Tg) is used as a tumor marker to monitor disease burden with treatment [232]. It detects recurrence in thyroid cancer with a sensitivity of $19-40 \%$ and specificity of $92-97 \%$ [233]. In addition, the presence of anti-thyroglobulin antibody in $25 \%$ of thyroid cancer patients affects the reliability of Tg assay $[234,235]$. Patients with poorly-differentiated thyroid cancers lose the ability to produce $\mathrm{Tg}$, making the measurement of $\mathrm{Tg}$ an unreliable reflection of tumor burden [232]. Given the low survival rate of aggressive thyroid cancer patients and the rather low sensitivity of $\mathrm{Tg}$ for detecting thyroid cancer recurrence leave room for the development of molecular tools that are more sensitive, and hopefully equally specific, than Tg.

The other underlying factor playing role in cancer treatment failure could be drug resistance, leading to elevated cancer relapse and mortality in patients [236,237]. ncRNAs are increasingly studied to unravel the complex mechanism of drug resistance development $[238,239]$. In this section, we discuss the recent advances contributing to the understanding of how ncRNAs contribute to drug sensitivity and/or resistance in thyroid cancer (Table 6).

Table 6. Therapeutic ncRNAs in thyroid cancer.

\begin{tabular}{|c|c|c|c|c|}
\hline ncRNA & ncRNA Type & $\begin{array}{l}\text { Therapeutic } \\
\text { Significance }\end{array}$ & $\begin{array}{c}\text { Thyroid } \\
\text { Cancer Type }\end{array}$ & Ref. \\
\hline miR-144 & \multirow{4}{*}{ miRNA } & $\begin{array}{c}\uparrow \text { Sensitivity to } \\
\text { cisplatin }\end{array}$ & ATC & [62] \\
\hline miR-146b & & $\begin{array}{c}\downarrow \text { Radioiodine } \\
\text { uptake }\end{array}$ & FTC & [215] \\
\hline miR-27b-3p & & $\begin{array}{c}\uparrow \text { Resistance to } \\
\text { doxorubicin }\end{array}$ & ATC & [240] \\
\hline miR-625-3p & & $\begin{array}{c}\text { Target of icariin } \\
\text { anti-tumor } \\
\text { substance }\end{array}$ & PTC & [56] \\
\hline MEG3a & \multirow{5}{*}{ lncRNA } & $\begin{array}{c}\uparrow \text { Resistance to } \\
\text { radioactive iodine }\end{array}$ & FTC and PTC & [241] \\
\hline NEAT1 & & $\begin{array}{l}\uparrow \text { Resistance to } \\
\text { cisplatin }\end{array}$ & ATC & [67] \\
\hline NEAT1 & & $\begin{array}{l}\uparrow \text { Resistance to } \\
\text { radioactive iodine }\end{array}$ & PTC & [242] \\
\hline PTCSC3 & & $\begin{array}{c}\uparrow \text { Resistance to } \\
\text { doxorubicin }\end{array}$ & ATC & [130] \\
\hline SLC6A9-5:2 & & $\begin{array}{l}\uparrow \text { Resistance to } \\
\text { radioactive iodine }\end{array}$ & PTC & [243] \\
\hline circEIF6 & circRNA & $\begin{array}{l}\uparrow \text { Resistance to } \\
\text { cisplatin }\end{array}$ & PTC and ATC & [142] \\
\hline
\end{tabular}

FTC: Follicular Thyroid Cancer; PTC: Papillary Thyroid Cancer; ATC: Anaplastic Thyroid Cancer; NEAT1: Nuclear Paraspeckle Assembly Transcript 1; MEG3a: Maternally Expressed Gene 3; PTCSC3: Papillary Thyroid Carcinoma Susceptibility Candidate 3; SLC6A9-5:2: Solute Carrier Family 6 Member 9-5:2; circEIF6: Circular Eukaryotic Translation Initiation Factor 6. 
Icariin, a chemical flavonoid compound isolated from different species of the genus Epimedium plant, has recently emerged as an anti-cancer substance [244], e.g., in ovarian cancer by targeting miR-21 [245] or in colorectal cancer through enhancing the NFkB suppression-mediated radiosensitivity [246]. In thyroid cancer, Fang et al. demonstrated that icariin inhibited cell growth, invasion and migration, while promoting apoptosis [56]. Mechanistically, icariin was shown to target miR-625-3p leading to inactivation of the $\mathrm{PI}_{3} \mathrm{~K} / \mathrm{Akt}$ and mitogen-activated protein kinase kinase (MEK)/mitogen-activated protein kinase 1 (ERK) signaling pathways [56]. Therefore, targeting miR-625-3p expression that is elevated in thyroid cancer could enhance the therapeutic sensitivity of tumor cells to icariin. In another study, $\mathrm{Xu}$ et al. reported that miR-27b-3p expression level was increased in doxorubicin-resistant ATC cells through targeting and suppressing peroxisome proliferator-activated receptor gamma (PPAR $\gamma$ ) gene [240]. Their findings indicated that targeted inhibition of miR-27b-3p might be a potential therapeutic approach in doxorubicin-resistant ATC cells. Another study on progressive ATC cells depicted that down-regulation of miR-144 led to the cisplatin resistance. Transfection with miR-144 mimics improved the sensitivity of ATC cells to cisplatin and inhibited tumor growth by suppressing (transforming growth factor alpha) TGF- $\alpha$ both in vitro and in vivo [62]. Collectively, the dysregulation of miRNAs could determine the sensitivity or resistance to the anti-tumor compounds in thyroid cancer (Figure 3). Together with drug screening, the miRNA microarray array clinical studies could provide more insights into the functional miRNAs involved in drug response.

To date, many lncRNAs have been shown in human cancer to play role as therapeutic determinants [247-249]. In thyroid cancer, lncRNAs have recently emerged as important factors involved in the sensitivity of patients to different treatments. LncRNA NEAT1 has been shown to have therapeutic implications in different thyroid cancer types. In ATC, in vitro and in vivo overexpression of NEAT1 was demonstrated to elevate cisplatin resistance via sponging miR-9-5p, which resulted in rescuing perm associated antigen 9 (SPAG9) [67]. In addition, higher expression of NEAT1 was detected in radioactivity iodine-resistant PTC tissues and cell lines, and this was associated with miR-101-3p inhibition, Fibronectin 1 overexpression, and $\mathrm{PI}_{3} \mathrm{~K} / \mathrm{Akt}$ pathway activation [242]. These highlight the importance of targeted inhibition of NEAT1 to overcome the chemotherapy and radioactivity iodine-resistance of thyroid cancer patients.

In addition to NEAT1, solute carrier family 6 member 9-5:2 (SLC6A9-5:2) and maternally expressed 3 (MEG3a) were discovered as therapeutic lncRNAs in determining the response to ${ }^{131}$ I therapy. MEG3a, an important lncRNA in different human diseases [250-252], was shown to be down-regulated in radioactivity iodine-resistant PTC and FTC tissues and cell lines. Mechanistically, overexpression of MEG3a resulted in sponging miR-182 that subsequently suppressed ${ }^{131}$ I-resistant cell viability and induced DNA damage [241]. Similarly, SLC6A9-5:2 down-regulation was reported in radioactivity iodine-resistant PTC tissues and cell lines. However, overexpression of SLC6A9-5:2 revoked the ${ }^{131}$ I-resistant sensitivity via up-regulating PARP-1 protein with an unknown mechanism [243]. IncRNA PTCSC 3 was observed to be down-regulated in ATC tissues and cell lines leading to increased STAT3 and INO80 expression. This axis consequently conferred resistance to doxorubicin [130]. This indicates that overexpressing PTCSC 3 could overcome the resistance to doxorubicin in ATC patients.

The physiological roles of circRNAs are not restricted to their contribution to cancer development. circRNAs, could also determine the drug response and thereby promote drug resistance in human cancers [253-257]. In thyroid cancer, circular eukaryotic translation initiation factor 6 (circEIF6) has been shown to inhibit the response to cisplatin. In the presence of this chemotherapeutic drug, circEIF6 was shown to inhibit the apoptosis via sponging miR-144-3p and the corresponding up-regulation of TGF- $\alpha$, thereby enhancing the resistance to cisplatin in both PTC and ATC thyroid cancer cells [142]. 
Collectively, ncRNAs play role as therapeutic factors in thyroid cancer (Figure 3). Altering miR-146b, NEAT1, MEG3a, SLC6A9-5:2 may synergistically improve the resistance to radioactive iodine, while targeted inhibition of miR-27b-3p and PTCSC 3 may overcome the resistance to doxorubicin. To heighten the sensitivity to cisplatin, miR-144, NEAT1 and circEIF6 could be studied together in thyroid cancer. Future studies could evaluate the functional role of ncRNAs in determining the response to targeted kinase therapy.

\section{Conclusions and Future Perspectives}

Over the years, remarkable progress has been achieved in mapping the genetic basis of thyroid cancer and developing more efficient molecular tests for its early detection. Notwithstanding, the overall survival of MTC, ATC, PDTC and metastatic differentiated thyroid cancer patients have not improved satisfactorily, reflecting the need for deciphering pristine molecular determinants that could guide early diagnosis and personalized treatment- utilization of ncRNAs is a promising strategy.

In this review, we discussed the current knowledge of three main subtypes of ncRNAs, including miRNAs, lncRNAs and circRNAs in different histopathological subtypes of thyroid cancer. Dysregulation of ncRNAs play an important role in thyroid cancer pathogenesis. This information could be utilized in the diagnostic, prognostic and therapeutic aspects of thyroid cancer clinical care. A number of clinical trials are ongoing to investigate the potential diagnostic and therapeutic impact of ncRNA molecules in thyroid cancer (Table 7).

Table 7. List of ongoing clinical trials indexed in ClinicalTrials.gov (https://clinicaltrials.gov/ct2/home) portal with diagnostic or prognostic relevance in thyroid cancer.

\begin{tabular}{ccccccc}
\hline Identifier & $\begin{array}{c}\text { ncRNA } \\
\text { Type }\end{array}$ & Type of Sample & Study Type & $\begin{array}{c}\text { Observational } \\
\text { Model }\end{array}$ & $\begin{array}{c}\text { Clinical } \\
\text { Significance }\end{array}$ & Status \\
\hline NCT03469544 & HOTAIR & $\begin{array}{c}\text { Peripheral blood } \\
\text { samples }\end{array}$ & Observational & Case-Control & $\begin{array}{c}\text { Diagnostic } \\
\text { biomarker }\end{array}$ & $\begin{array}{c}\text { Not yet } \\
\text { recruiting }\end{array}$ \\
\hline NCT01964508 & miRNAs & FNA samples & Observational & Cohort & $\begin{array}{c}\text { Diagnostic } \\
\text { biomarker }\end{array}$ & $\begin{array}{c}\text { Not yet } \\
\text { recruiting }\end{array}$ \\
\hline NCT04594720 & IncRNAs & $\begin{array}{c}\text { Peripheral blood } \\
\text { samples }\end{array}$ & Observational & Case-Control & $\begin{array}{c}\text { Diagnostic } \\
\text { biomarker }\end{array}$ & $\begin{array}{c}\text { Recruiting } \\
\text { completed }\end{array}$ \\
\hline NCT01240590 & miRNAs & ATC tumor samples & Interventional & $\begin{array}{c}\text { Parallel } \\
\text { Assignment }\end{array}$ & $\begin{array}{c}\text { Therapeutic } \\
\text { biomarker } \\
\text { for }\end{array}$ & $\begin{array}{c}\text { Recruiting } \\
\text { Crolibulin } \\
\text { and cisplatin }\end{array}$ \\
\hline NCT04285476 & miRNAs & Thyroid carcinoma & Interventional & $\begin{array}{c}\text { Single Group } \\
\text { Assignment }\end{array}$ & $\begin{array}{c}\text { Diagnostic } \\
\text { biomarker }\end{array}$ & $\begin{array}{c}\text { Not yet } \\
\text { recruiting }\end{array}$ \\
\hline NCT00689065 & siRNA & $\begin{array}{c}\text { Variety of solid } \\
\text { tumors including } \\
\text { Thyroid carcinoma }\end{array}$ & Interventional & $\begin{array}{c}\text { Single Group } \\
\text { Assignment }\end{array}$ & $\begin{array}{c}\text { RNA-based } \\
\text { therapy } \\
\text { (CALAA-01) }\end{array}$ & $\begin{array}{c}\text { Recruitment } \\
\text { terminated }\end{array}$ \\
\hline
\end{tabular}

FNA: fine needle aspiration.

Owing to the tumor-suppressive or oncogenic function, dysregulated ncRNAs could promote tumorigenesis via regulating various physiological and cellular activities leading to proliferation/cell growth or inhibition of cell death. However, little is known about the detailed regulatory mechanisms by which the ncRNAs, especially circRNAs, are dysregulated in thyroid cancer with the corresponding downstream tumorigenic and drug-resistance cascades. Understanding the mode of action by which different ncRNAs, individually or in a network, impose their oncogenic effects could aid in the development of new therapeutic approaches to harness the progression of malignant cells. This could be primarily achieved by rational in vitro RNA-based drug design to target the up-regulated ncRNAs using antagomirs and antisense oligos (ASOs), or by expressing the key down-regulated ncRNAs using agomirs and expression vectors. However, selecting the key target ncRNAs from a large number of candidate ncRNAs remains a big challenge. 
The other challenge would be the instability and high immunogenicity of the RNA therapeutics, necessitating chemical modifications of the RNA molecules. One example is using the inverted thymidine residues at the $3^{\prime}$ end of the RNA to protect it against exonucleases, thereby improving stability [258]. In addition, conjugating the RNA with an active targeting moiety, such as an antibody, has been shown to reduce immunogenicity [259]. Although significant progress has been made, the delivery of RNA therapeutics remains a major challenge. Negatively charged phosphate backbones and large molecular weight of RNA molecules hamper RNA uptake through difficulties in passing through the cell membrane, micropinocytosis, endosomal escape and kidney clearance [258,260,261]. In addition to reducing immunogenicity, the conjugation of RNAs with targeting moieties including antibodies, aptamers, lipic nanoparticles and polymers has led to magnificent advances in the delivery efficiency of RNA therapeutics [262]. Attachment of a monoclonal antibody (TCM-9), a specific antibody for human thyroid cancer [263], could be a strategy to improve the targeted delivery of RNA therapeutics to thyroid carcinoma cells.

Combination of ncRNAs-based therapeutic interventions with conventional systemic therapy could emerge as an impactful way to conquer drug resistance in advanced thyroid cancer. Such in-depth studies may prove the way toward pre-clinical and clinical investigations that eventually could provide more impactful therapies. Beyond the understanding of cancer pathogenesis and drug resistance, the alteration in circulating or tissue ncRNAs expression could facilitate the diagnosis of different thyroid malignancies with improved sensitivity and specificity, and a minimized need for diagnostic thyroid surgeries. Taken together, we expect the application of ncRNAs as diagnostic/prognostic biomarkers and therapeutic targets to emerge within the few next years in thyroid cancer.

Author Contributions: Y.T. and S.P.Y. participated in the conception and revision of the manuscript, H.T. participated in writing the manuscript and preparing the figures. All authors read and approved the final version of this manuscript.

Funding: This work is supported by funding from the NUHS clinician scientist program (NCSP), National Medical Research Council (NMRC) Research Fellowship, Singapore National Research Foundation Fellowship, National University of Singapore President's Assistant Professorship, and the RNA Biology Center at CSI Singapore, NUS, from funding by the Singapore Ministry of Education's Tier 3 grant number [MOE2014-T3-1-006].

Acknowledgments: The figures were created using BioRender.

Conflicts of Interest: The authors declare no conflict of interest.

\section{Abbreviations}

$\begin{array}{ll}\text { ADAM9 } & \text { ADAM Metallopeptidase Domain 9 } \\ \text { AKT3 } & \text { RAC- } \gamma \text { serine/threonine-protein kinase } \\ \text { AMPK } & 5^{\prime} \text { AMP-activated Protein Kinase } \\ \text { ATC } & \text { Anaplastic Thyroid Cancer } \\ \text { BDNF } & \text { Brain-Derived Neurotrophic Factor } \\ \text { CASC9 } & \text { Cancer Susceptibility 9 } \\ \text { CCND1 } & \text { Cyclin D1 } \\ \text { CDH6 } & \text { Cadherin 6 } \\ \text { circEIF6 } & \text { Circular Eukaryotic Translation Initiation Factor 6 } \\ \text { circFOXM1 } & \text { Circular Forkhead Box Protein M1 } \\ \text { circRNA } & \text { Circular RNA } \\ \text { CXCL16 } & \text { C-X-C Motif Chemokine Ligand 16 } \\ \text { DLX6-AS1 } & \text { Distal-Less Homeobox 6-Antisense 1 } \\ \text { EGFR } & \text { Epidermal Growth Factor Receptor } \\ \text { ERBB2 } & \text { Erb-B2 Receptor Tyrosine Kinase 2 } \\ \text { ER- } \beta & \text { Estrogen Receptor Beta } \\ \text { EZH2 } & \text { Enhancer of Zeste Homolog 2 } \\ \text { FGF2 } & \text { Fibroblast Growth Factor }\end{array}$




\begin{tabular}{|c|c|}
\hline FGFR2 & Fibroblast Growth Factor Receptor 2 \\
\hline FNA & Fine Needle Aspiration \\
\hline FOXE1 & Forkhead Box E1 \\
\hline FOXN3 & Forkhead Box N3 \\
\hline FOXO1 & Forkhead Box O1 \\
\hline FTC & Follicular Thyroid Carcinoma \\
\hline HCP5 & HLA complex P5 \\
\hline HK2 & Hexokinase 2 \\
\hline HMGB1 & High Mobility Group Box Protein 1 \\
\hline ITGA3 & Integrin Subunit Alpha 3 \\
\hline $\operatorname{lncRNA}$ & Long Non-coding RNA \\
\hline MALAT1 & Metastasis Associated Lung Adenocarcinoma Transcript 1 \\
\hline MEG3a & Maternally Expressed Gene 3 \\
\hline miRNA & microRNA \\
\hline MMP1 & Matrix Metallopeptidase 1 \\
\hline MTC & Medullary Thyroid Carcinoma \\
\hline mTOR & Mechanistic Target of Rapamycin Kinase \\
\hline ncRNA & Non-coding RNA \\
\hline NEAT1 & Nuclear Paraspeckle Assembly Transcript 1 \\
\hline PAK1 & p21 Activated Kinase-1 \\
\hline PAR5 & Prader Willi/Angelman Region RNA5 \\
\hline PDTC & Poorly differentiated thyroid carcinoma \\
\hline $\mathrm{PI}_{3} \mathrm{~K}$ & Phosphatidylinositol-4,5-Bisphosphate 3-Kinase \\
\hline piRNA & PIWI-interacting RNA: \\
\hline PTC & Papillary Thyroid Cancer \\
\hline PTCSC3 & Thyroid Carcinoma Susceptibility Candidate 3 \\
\hline PTCSCs & Papillary Thyroid Cancer Stem Cells \\
\hline QKI5-7 & Quaking protein 5-7 \\
\hline RAR- $\beta$ & Retinoic Acid Receptor Beta \\
\hline ROCK1 & Rho-associated Protein Kinase 1 \\
\hline SCAI & Suppressor of Cancer Cell Invasion \\
\hline SEER & Surveillance, Epidemiology and End Results \\
\hline SLC6A9-5:2 & Solute Carrier Family 6 Member 9-5:2 \\
\hline SNHG3 & Small Nucleolar RNA Host Gene 3 \\
\hline snoRNA & Small nuclear RNA \\
\hline SOCS1 & Suppressor Protein of Cytokine Signaling 1 \\
\hline SPAG9 & Perm Associated Antigen 9 \\
\hline ST6GAL2 & alpha-2, 6-sialyltransferase 2 \\
\hline STAT3 & Signal Transducer And Activator of Transcription 3 \\
\hline STON2 & Stonin 2 \\
\hline TGF- $\alpha$ & Transforming Growth Factor Alpha \\
\hline UNC5B-AS1 & Unc-5 Netrin Receptor B-Antisense RNA 1 \\
\hline UPF1 & UPF1 RNA Helicase and ATPase \\
\hline VHL & Von Hippel-Lindau Tumor Suppressor \\
\hline XIST & $X$-inactive specific transcript \\
\hline YY1 & Yin Yang 1 \\
\hline
\end{tabular}

\section{References}

1. Katoh, H.; Yamashita, K.; Enomoto, T.; Watanabe, M. Classification and general considerations of thyroid cancer. Ann. Clin. Pathol. 2015, 3, 1045.

2. James, B.C.; Mitchell, J.M.; Jeon, H.D.; Vasilottos, N.; Grogan, R.H.; Aschebrook-Kilfoy, B. An update in international trends in incidence rates of thyroid cancer, 1973-2007. Cancer Causes Control 2018, 29, 465-473. [CrossRef] 
3. Bray, F.; Ferlay, J.; Soerjomataram, I.; Siegel, R.L.; Torre, L.A.; Jemal, A. Global cancer statistics 2018: GLOBOCAN estimates of incidence and mortality worldwide for 36 cancers in 185 countries. CA Cancer J. Clin. 2018, 68, 394-424. [CrossRef]

4. Davies, L.; Morris, L.; Hankey, B. Increases in thyroid cancer incidence and mortality. JAMA 2017, 318, 389-390. [CrossRef] [PubMed]

5. National Cancer Institute. Surveillance, Epidemiology and End Results (SEER) Program. Available online: https://seer.cancer.gov/statfacts/html/thyro.htm (accessed on 4 October 2020).

6. Fiore, M.; Oliveri Conti, G.; Caltabiano, R.; Buffone, A.; Zuccarello, P.; Cormaci, L.; Cannizzaro, M.A.; Ferrante, M. Role of emerging environmental risk factors in thyroid cancer: A brief review. Int. J. Environ. Res. Public Health 2019, 16, 1185. [CrossRef] [PubMed]

7. Thun, M.; Linet, M.S.; Cerhan, J.R.; Haiman, C.A.; Schottenfeld, D. Cancer Epidemiology and Prevention; Oxford University Press: Oxford, UK, 2017.

8. Pirahanchi, Y.; Jialal, I. Physiology, thyroid. In StatPearls; StatPearls Publishing: Treasure Island, FL, USA, 2018.

9. Soundarrajan, M.; Kopp, P.A. Thyroid Hormone Biosynthesis and Physiology. In Thyroid Disease and Reproduction; Springer: Berlin/Heidelberg, Germany, 2019; pp. 1-17.

10. Romei, C.; Tacito, A.; Molinaro, E.; Piaggi, P.; Cappagli, V.; Pieruzzi, L.; Matrone, A.; Viola, D.; Agate, L.; Torregrossa, L. Clinical, pathological and genetic features of anaplastic and poorly differentiated thyroid cancer: A single institute experience. Oncol. Lett. 2018, 15, 9174-9182. [CrossRef] [PubMed]

11. Sipos, J.; Mazzaferri, E. Thyroid cancer epidemiology and prognostic variables. Clin. Oncol. 2010, $22,395-404$. [CrossRef] [PubMed]

12. Fugazzola, L.; Elisei, R.; Fuhrer, D.; Jarzab, B.; Leboulleux, S.; Newbold, K.; Smit, J. 2019 European Thyroid Association Guidelines for the Treatment and Follow-Up of Advanced Radioiodine-Refractory Thyroid Cancer. Eur. Thyroid J. 2019, 8, 227-245. [CrossRef]

13. Haugen, B.R.; Alexander, E.K.; Bible, K.C.; Doherty, G.M.; Mandel, S.J.; Nikiforov, Y.E.; Pacini, F.; Randolph, G.W.; Sawka, A.M.; Schlumberger, M. 2015 American Thyroid Association management guidelines for adult patients with thyroid nodules and differentiated thyroid cancer: The American Thyroid Association guidelines task force on thyroid nodules and differentiated thyroid cancer. Thyroid 2016, 26, 1-133. [CrossRef] [PubMed]

14. Grewal, R.K.; Ho, A.; Schöder, H. Novel approaches to thyroid cancer treatment and response assessment. Semin. Nucl. Med. 2016, 46, 109-118. [CrossRef]

15. Nikiforov, Y.E.; Ohori, N.P.; Hodak, S.P.; Carty, S.E.; LeBeau, S.O.; Ferris, R.L.; Yip, L.; Seethala, R.R.; Tublin, M.E.; Stang, M.T. Impact of mutational testing on the diagnosis and management of patients with cytologically indeterminate thyroid nodules: A prospective analysis of 1056 FNA samples. J. Clin. Endocrinol. Metab. 2011, 96, 3390-3397. [CrossRef]

16. Nikiforov, Y.E.; Carty, S.E.; Chiosea, S.I.; Coyne, C.; Duvvuri, U.; Ferris, R.L.; Gooding, W.E.; Hodak, S.P.; LeBeau, S.O.; Ohori, N.P. Highly accurate diagnosis of cancer in thyroid nodules with follicular neoplasm/suspicious for a follicular neoplasm cytology by ThyroSeq v2 next-generation sequencing assay. Cancer 2014, 120, 3627-3634. [CrossRef]

17. Santhanam, P.; Khthir, R.; Gress, T.; Elkadry, A.; Olajide, O.; Yaqub, A.; Driscoll, H. Gene expression classifier for the diagnosis of indeterminate thyroid nodules: A meta-analysis. Med. Oncol. 2016, 33, 14. [CrossRef]

18. Fagin, J.A.; Wells, S.A., Jr. Biologic and clinical perspectives on thyroid cancer. New Engl. J. Med. 2016, 375, 1054-1067. [CrossRef] [PubMed]

19. Liu, R.; Xing, M. TERT promoter mutations in thyroid cancer. Endocr. Relat. Cancer 2016, 23, R143-R155. [CrossRef]

20. Lathief, S.; Pothuloori, A.; Liu, X.; Chaidarun, S. Advances and practical use of the molecular markers for thyroid cancer. Adv. Cell. Mol. Otolaryngol. 2016, 4, 33948. [CrossRef]

21. Lin, C.; Yang, L. Long noncoding RNA in cancer: Wiring signaling circuitry. Trends Cell Biol. 2018, 28, 287-301. [CrossRef] [PubMed]

22. Agostini, M.; Ganini, C.; Candi, E.; Melino, G. The role of noncoding RNAs in epithelial cancer. Cell Death Discov. 2020, 6, 13. [CrossRef]

23. Choudhari, R.; Sedano, M.J.; Harrison, A.L.; Subramani, R.; Lin, K.Y.; Ramos, E.I.; Lakshmanaswamy, R.; Gadad, S.S. Long noncoding RNAs in cancer: From discovery to therapeutic targets. In Advances in Clinical Chemistry; Elsevier: Amsterdam, The Netherlands, 2020; Volume 95, pp. 105-147. 
24. Sohel, M.M.H. Circulating microRNAs as biomarkers in cancer diagnosis. Life Sci. 2020, 117473. [CrossRef]

25. Wright, M.W.; Bruford, E.A. Naming'junk: Human non-protein coding RNA (ncRNA) gene nomenclature. Hum. Genom. 2011, 5, 90. [CrossRef]

26. Esteller, M.; Pandolfi, P.P. The epitranscriptome of noncoding RNAs in cancer. Cancer Discov. 2017, 7, 359-368. [CrossRef]

27. Lü, L.; Sun, J.; Shi, P.; Kong, W.; Xu, K.; He, B.; Zhang, S.; Wang, J. Identification of circular RNAs as a promising new class of diagnostic biomarkers for human breast cancer. Oncotarget 2017, 8, 44096. [CrossRef]

28. Wang, W.-J.; Li, H.-T.; Yu, J.-P.; Han, X.-P.; Xu, Z.-P.; Li, Y.-M.; Jiao, Z.-Y.; Liu, H.-B. A competing endogenous RNA network reveals novel potential lncRNA, miRNA, and mRNA biomarkers in the prognosis of human colon adenocarcinoma. J. Surg. Res. 2019, 235, 22-33. [CrossRef] [PubMed]

29. Mai, D.; Ding, P.; Tan, L.; Zhang, J.; Pan, Z.; Bai, R.; Li, C.; Li, M.; Zhou, Y.; Tan, W. PIWI-interacting RNA-54265 is oncogenic and a potential therapeutic target in colorectal adenocarcinoma. Theranostics 2018, 8, 5213. [CrossRef]

30. Qin, X.-g.; Zeng, J.-H.; Lin, P.; Mo, W.-J.; Li, Q.; Feng, Z.-B.; Luo, D.-Z.; Yang, H.; Chen, G.; Zeng, J.-J. Prognostic value of small nuclear RNAs (snRNAs) for digestive tract pan-adenocarcinomas identified by RNA sequencing data. Pathol. Res. Pract. 2019, 215, 414-426. [CrossRef]

31. Zhang, P.; Wu, W.; Chen, Q.; Chen, M. Non-Coding RNAs and their Integrated Networks. J. Integr. Bioinform. 2019, 16. [CrossRef]

32. Yang, L. Splicing noncoding RNAs from the inside out. Wiley Interdiscip. Rev. RNA 2015, 6, 651-660. [CrossRef]

33. Khorshidi, A.; Dhaliwal, P.; Yang, B.B. Noncoding RNAs in tumor angiogenesis. In The Long and Short Non-Coding RNAs in Cancer Biology; Springer: Berlin/Heidelberg, Germany, 2016; pp. 217-241.

34. Tang, X.J.; Wang, W.; Hann, S.S. Interactions among lncRNAs, miRNAs and mRNA in colorectal cancer. Biochimie 2019, 163, 58-72. [CrossRef] [PubMed]

35. Xu, S.; Gong, Y.; Yin, Y.; Xing, H.; Zhang, N. The multiple function of long noncoding RNAs in osteosarcoma progression, drug resistance and prognosis. Biomed. Pharmacother. 2020, 127, 110141. [CrossRef]

36. Rossi, M.; Gorospe, M. Noncoding RNAs Controlling Telomere Homeostasis in Senescence and Aging. Trends Mol. Med. 2020, 26, 422-433. [CrossRef]

37. Guzel, E.; Okyay, T.M.; Yalcinkaya, B.; Karacaoglu, S.; Gocmen, M.; Akcakuyu, M.H. Tumor suppressor and oncogenic role of long non-coding RNAs in cancer. North. Clin. Istanb. 2020, 7, 81. [CrossRef]

38. Dhamija, S.; Diederichs, S. From junk to master regulators of invasion: LncRNA functions in migration, EMT and metastasis. Int. J. Cancer 2016, 139, 269-280. [CrossRef]

39. Huang, Z.; Zhou, J.-K.; Peng, Y.; He, W.; Huang, C. The role of long noncoding RNAs in hepatocellular carcinoma. Mol. Cancer 2020, 19, 1-18. [CrossRef]

40. Liu, K.; Gao, L.; Ma, X.; Huang, J.-J.; Chen, J.; Zeng, L.; Ashby, C.R.; Zou, C.; Chen, Z.-S. Long non-coding RNAs regulate drug resistance in cancer. Mol. Cancer 2020, 19, 1-13. [CrossRef]

41. Li, Z.; Ruan, Y.; Zhang, H.; Shen, Y.; Li, T.; Xiao, B. Tumor-suppressive circular RNAs: Mechanisms underlying their suppression of tumor occurrence and use as therapeutic targets. Cancer Sci. 2019, 110, 3630. [CrossRef]

42. Shukla, G.C.; Singh, J.; Barik, S. MicroRNAs: Processing, maturation, target recognition and regulatory functions. Mol. Cell. Pharmacol. 2011, 3, 83.

43. Markopoulos, G.S.; Roupakia, E.; Tokamani, M.; Chavdoula, E.; Hatziapostolou, M.; Polytarchou, C.; Marcu, K.B.; Papavassiliou, A.G.; Sandaltzopoulos, R.; Kolettas, E. A step-by-step microRNA guide to cancer development and metastasis. Cell. Oncol. 2017, 40, 303-339. [CrossRef]

44. Dai, X.; Kaushik, A.C.; Zhang, J. The emerging role of major regulatory RNAs in cancer control. Front. Oncol. 2019, 9, 920. [CrossRef]

45. Zong, Y.; Zhang, Y.; Sun, X.; Xu, T.; Cheng, X.; Qin, Y. miR-221/222 promote tumor growth and suppress apoptosis by targeting lncRNA GAS5 in breast cancer. Biosci. Rep. 2019, 39. [CrossRef] [PubMed]

46. Ma, C.; Zhan, C.; Yuan, H.; Cui, Y.; Zhang, Z. MicroRNA-603 functions as an oncogene by suppressing BRCC2 protein translation in osteosarcoma. Oncol. Rep. 2016, 35, 3257-3264. [CrossRef]

47. Zeng, B.; Li, Y.; Jiang, F.; Wei, C.; Chen, G.; Zhang, W.; Zhao, W.; Yu, D. LncRNA GAS5 suppresses proliferation, migration, invasion, and epithelial-mesenchymal transition in oral squamous cell carcinoma by regulating the miR-21/PTEN axis. Exp. Cell Res. 2019, 374, 365-373. [CrossRef] 
48. Calin, G.A.; Dumitru, C.D.; Shimizu, M.; Bichi, R.; Zupo, S.; Noch, E.; Aldler, H.; Rattan, S.; Keating, M.; Rai, K. Frequent deletions and down-regulation of micro-RNA genes miR15 and miR16 at 13q14 in chronic lymphocytic leukemia. Proc. Natl. Acad. Sci. USA 2002, 99, 15524-15529. [CrossRef]

49. He, H.; Jazdzewski, K.; Li, W.; Liyanarachchi, S.; Nagy, R.; Volinia, S.; Calin, G.A.; Liu, C.-g.; Franssila, K.; Suster, S. The role of microRNA genes in papillary thyroid carcinoma. Proc. Natl. Acad. Sci. USA 2005, 102, 19075-19080. [CrossRef]

50. Zembska, A.; Jawiarczyk-Przybyłowska, A.; Wojtczak, B.; Bolanowski, M. MicroRNA expression in the progression and aggressiveness of papillary thyroid carcinoma. Anticancer Res. 2019, 39, 33-40. [CrossRef]

51. Pishkari, S.; Paryan, M.; Hashemi, M.; Baldini, E.; Mohammadi-Yeganeh, S. The role of microRNAs in different types of thyroid carcinoma: A comprehensive analysis to find new miRNA supplementary therapies. J. Endocrinol. Investig. 2018, 41, 269-283. [CrossRef] [PubMed]

52. Czajka, A.A.; Wojcicka, A.; Kubiak, A.; Kotlarek, M.; Bakuła-Zalewska, E.; Koperski, Ł.; Wiechno, W.; Jażdżewski, K. Family of microRNA-146 regulates RAR $\beta$ in papillary thyroid carcinoma. PLoS ONE 2016, 11, e0151968. [CrossRef]

53. Zhang, W.; Ji, W.; Zhao, X. MiR-155 promotes anaplastic thyroid cancer progression by directly targeting SOCS1. BMC Cancer 2019, 19, 1093. [CrossRef]

54. Zang, C.; Sun, J.; Liu, W.; Chu, C.; Jiang, L.; Ge, R. miRNA-21 promotes cell proliferation and invasion via VHL/PI3K/AKT in papillary thyroid carcinoma. Hum. Cell 2019, 32, 428-436. [CrossRef]

55. Wang, X.; Lu, X.; Geng, Z.; Yang, G.; Shi, Y. LncRNA PTCSC3/miR-574-5p governs cell proliferation and migration of papillary thyroid carcinoma via Wnt/ $\beta$-catenin signaling. J. Cell. Biochem. 2017, 118, 4745-4752. [CrossRef] [PubMed]

56. Fang, L.; Xu, W.; Kong, D. Icariin inhibits cell proliferation, migration and invasion by down-regulation of microRNA-625-3p in thyroid cancer cells. Biomed. Pharmacother. 2019, 109, 2456-2463. [CrossRef]

57. Wang, X.-Z.; Hang, Y.-K.; Liu, J.-B.; Hou, Y.-Q.; Wang, N.; Wang, M.-J. Over-expression of microRNA-375 inhibits papillary thyroid carcinoma cell proliferation and induces cell apoptosis by targeting ERBB2. J. Pharmacol. Sci. 2016, 130, 78-84. [CrossRef]

58. Liu, N.; Zhou, Q.; Qi, Y.-H.; Wang, H.; Yang, L.; Fan, Q.-Y. Effects of long non-coding RNA H19 and microRNA let7a expression on thyroid cancer prognosis. Exp. Mol. Pathol. 2017, 103, 71-77. [CrossRef]

59. Huang, P.; Mao, L.-F.; Zhang, Z.-P.; Lv, W.-W.; Feng, X.-P.; Liao, H.-J.; Dong, C.; Kaluba, B.; Tang, X.-F.; Chang, S. Down-regulated miR-125a-5p promotes the reprogramming of glucose metabolism and cell malignancy by increasing levels of CD147 in thyroid cancer. Thyroid 2018, 28, 613-623. [CrossRef]

60. Fu, Y.; Zheng, H.; Zhang, D.; Zhou, L.; Sun, H. MicroRNA-1266 suppresses papillary thyroid carcinoma cell metastasis and growth via targeting FGFR2. Eur. Rev. Med. Pharm. Sci. 2018, 22, 3430-3438.

61. Fang, M.; Huang, W.; Wu, X.; Gao, Y.; Ou, J.; Zhang, X.; Li, Y. MiR-141-3p suppresses tumor growth and metastasis in papillary thyroid cancer via targeting Yin Yang 1. Anat. Rec. 2019, 302, 258-268. [CrossRef]

62. Liu, J.; Feng, L.; Zhang, H.; Zhang, J.; Zhang, Y.; Li, S.; Qin, L.; Yang, Z.; Xiong, J. Effects of miR-144 on the sensitivity of human anaplastic thyroid carcinoma cells to cisplatin by autophagy regulation. Cancer Biol. Ther. 2018, 19, 484-496. [CrossRef]

63. Sheng, W.; Chen, Y.; Gong, Y.; Dong, T.; Zhang, B.; Gao, W. miR-148a inhibits self-renewal of thyroid cancer stem cells via repressing INO80 expression. Oncol. Rep. 2016, 36, 3387-3396. [CrossRef]

64. Cheng, L.; Zhou, R.; Chen, M.; Feng, L.; Li, H. MicroRNA-150 targets Rho-associated protein kinase 1 to inhibit cell proliferation, migration and invasion in papillary thyroid carcinoma. Mol. Med. Rep. 2017, 16, 2217-2224. [CrossRef] [PubMed]

65. Yin, Y.; Hong, S.; Yu, S.; Huang, Y.; Chen, S.; Liu, Y.; Zhang, Q.; Li, Y.; Xiao, H. MiR-195 inhibits tumor growth and metastasis in papillary thyroid carcinoma cell lines by targeting CCND1 and FGF2. Int. J. Endocrinol. 2017, 2017, 6180425. [CrossRef] [PubMed]

66. Ren, L.; Xu, Y.; Qin, G.; Liu, C.; Yan, Y.; Zhang, H. miR-199b-5p-Stonin 2 axis regulates metastases and epithelial-to-mesenchymal transition of papillary thyroid carcinoma. IUBMB Life 2019, 71, 28-40. [CrossRef]

67. Liu, H.; Chen, X.; Lin, T.; Chen, X.; Yan, J.; Jiang, S. MicroRNA-524-5p suppresses the progression of papillary thyroid carcinoma cells via targeting on FOXE1 and ITGA3 in cell autophagy and cycling pathways. J. Cell. Physiol. 2019, 234, 18382-18391. [CrossRef]

68. Yue, K.; Wang, X.; Wu, Y.; Zhou, X.; He, Q.; Duan, Y. microRNA-7 regulates cell growth, migration and invasion via direct targeting of PAK1 in thyroid cancer. Mol. Med. Rep. 2016, 14, 2127-2134. [CrossRef] 
69. Wang, Z.; Liu, W.; Wang, C.; Ai, Z. miR-873-5p Inhibits Cell Migration and Invasion of Papillary Thyroid Cancer via Regulation of CXCL16. Oncotargets Ther. 2020, 13, 1037. [CrossRef]

70. Guo, F.; Hou, X.; Sun, Q. MicroRNA-9-5p functions as a tumor suppressor in papillary thyroid cancer via targeting BRAF. Oncol. Lett. 2018, 16, 6815-6821. [CrossRef] [PubMed]

71. Sastre-Perona, A.; Santisteban, P. Role of the wnt pathway in thyroid cancer. Front. Endocrinol. 2012, 3, 31. [CrossRef]

72. Fuziwara, C.S.; Kimura, E.T. How does microRNA modulate Wnt/ $\beta$-catenin signaling in thyroid oncogenesis? Ann. Transl. Med. 2020, 8, 266. [CrossRef]

73. Ely, K.A.; Bischoff, L.A.; Weiss, V.L. Wnt signaling in thyroid homeostasis and carcinogenesis. Genes 2018, 9, 204. [CrossRef]

74. Zhang, Z.-J.; Xiao, Q.; Li, X.-Y. MicroRNA-574-5p directly targets FOXN3 to mediate thyroid cancer progression via Wnt/ $\beta$-catenin signaling pathway. Pathol. Res. Pract. 2020, 216, 152939. [CrossRef] [PubMed]

75. Zhang, Z.; Li, X.; Xiao, Q.; Wang, Z. MiR-574-5p mediates the cell cycle and apoptosis in thyroid cancer cells via Wnt/ $\beta$-catenin signaling by repressing the expression of Quaking proteins. Oncol. Lett. 2018, 15, 5841-5848. [CrossRef]

76. Feige, J.; Cherradi, N. Serum miR-483-5p and miR-195 are predictive of recurrence risk in adrenocortical cancer patients. Endocr. Relat. Cancer 2013, 20, 579-594.

77. Liu, B.; Qu, J.; Xu, F.; Guo, Y.; Wang, Y.; Yu, H.; Qian, B. MiR-195 suppresses non-small cell lung cancer by targeting CHEK1. Oncotarget 2015, 6, 9445. [CrossRef]

78. Ujifuku, K.; Mitsutake, N.; Takakura, S.; Matsuse, M.; Saenko, V.; Suzuki, K.; Hayashi, K.; Matsuo, T.; Kamada, K.; Nagata, I. MiR-195, miR-455-3p and miR-10a* are implicated in acquired temozolomide resistance in glioblastoma multiforme cells. Cancer Lett. 2010, 296, 241-248. [CrossRef]

79. Liu, X.; Zhou, Y.; Ning, Y.-E.; Gu, H.; Tong, Y.; Wang, N. MiR-195-5p Inhibits Malignant Progression of Cervical Cancer by Targeting YAP1. Oncotargets Ther. 2020, 13, 931. [CrossRef]

80. Balmeh, N.; Tabatabaeian, H.; Asgari, M.; Mokhtarian, R.; Abharian, P.H.; Azadeh, M.; Ghaedi, K. miR-195 down-regulation is a distinctive biomarker of HER2 positive state in breast cancer. Gene Rep. 2020, 100703. [CrossRef]

81. Jung, Y.-S.; Park, J.-I. Wnt signaling in cancer: Therapeutic targeting of Wnt signaling beyond $\beta$-catenin and the destruction complex. Exp. Mol. Med. 2020, 52, 183-191. [CrossRef]

82. Noorolyai, S.; Shajari, N.; Baghbani, E.; Sadreddini, S.; Baradaran, B. The relation between PI3K/AKT signalling pathway and cancer. Gene 2019, 698, 120-128. [CrossRef]

83. Nozhat, Z.; Hedayati, M. PI3K/AKT pathway and its mediators in thyroid carcinomas. Mol. Diagn. Ther. 2016, 20, 13-26. [CrossRef]

84. Zhang, J.-G.; Wang, J.-J.; Zhao, F.; Liu, Q.; Jiang, K.; Yang, G.-h. MicroRNA-21 (miR-21) represses tumor suppressor PTEN and promotes growth and invasion in non-small cell lung cancer (NSCLC). Clin. Chim. Acta 2010, 411, 846-852. [CrossRef]

85. Li, L.-Q.; Li, X.-L.; Wang, L.; Du, W.-J.; Guo, R.; Liang, H.-H.; Liu, X.; Liang, D.-S.; Lu, Y.-J.; Shan, H.-L. Matrine inhibits breast cancer growth via miR-21/PTEN/Akt pathway in MCF-7 cells. Cell. Physiol. Biochem. 2012, 30, 631-641. [CrossRef] [PubMed]

86. McClelland, A.D.; Herman-Edelstein, M.; Komers, R.; Jha, J.C.; Winbanks, C.E.; Hagiwara, S.; Gregorevic, P.; Kantharidis, P.; Cooper, M.E. miR-21 promotes renal fibrosis in diabetic nephropathy by targeting PTEN and SMAD7. Clin. Sci. 2015, 129, 1237-1249. [CrossRef]

87. Haugen, D.; Akslen, L.; Varhaug, J.A.; Lillehaug, J. Expression of c-erb B-2 protein in papillary thyroid carcinomas. Br. J. Cancer 1992, 65, 832-837. [CrossRef]

88. Montero-Conde, C.; Ruiz-Llorente, S.; Dominguez, J.M.; Knauf, J.A.; Viale, A.; Sherman, E.J.; Ryder, M.; Ghossein, R.A.; Rosen, N.; Fagin, J.A. Relief of feedback inhibition of HER3 transcription by RAF and MEK inhibitors attenuates their antitumor effects in BRAF-mutant thyroid carcinomas. Cancer Discov. 2013, 3, 520-533. [CrossRef]

89. Lv, Y.; Sui, F.; Ma, J.; Ren, X.; Yang, Q.; Zhang, Y.; Guan, H.; Shi, B.; Hou, P.; Ji, M. Increased expression of EHF contributes to thyroid tumorigenesis through transcriptionally regulating HER2 and HER3. Oncotarget 2016, 7, 57978. [CrossRef]

90. Zaballos, M.A.; Santisteban, P. FOXO1 controls thyroid cell proliferation in response to TSH and IGF-I and is involved in thyroid tumorigenesis. Mol. Endocrinol. 2013, 27, 50-62. [CrossRef] 
91. Rena, G.; Prescott, A.R.; Guo, S.; Cohen, P.; Unterman, T.G. Roles of the forkhead in rhabdomyosarcoma (FKHR) phosphorylation sites in regulating 14-3-3 binding, transactivation and nuclear targetting. Biochem. J. 2001, 354, 605-612. [CrossRef]

92. Wong, K.; Di Cristofano, F.; Ranieri, M.; De Martino, D.; Di Cristofano, A. PI3K/mTOR inhibition potentiates and extends palbociclib activity in anaplastic thyroid cancer. Endocr. Relat. Cancer 2019, 26, 425-436. [CrossRef]

93. Coelho, R.G.; Fortunato, R.S.; Carvalho, D.P. Metabolic reprogramming in thyroid carcinoma. Front. Oncol. 2018, 8, 82. [CrossRef]

94. Suh, H.Y.; Choi, H.; Paeng, J.C.; Cheon, G.J.; Chung, J.-K.; Kang, K.W. Comprehensive gene expression analysis for exploring the association between glucose metabolism and differentiation of thyroid cancer. BMC Cancer 2019, 19, 1260. [CrossRef]

95. Miao, Y.; Zhang, L.-F.; Zhang, M.; Guo, R.; Liu, M.-F.; Li, B. Therapeutic Delivery of miR-143 Targeting Tumor Metabolism in Poorly Differentiated Thyroid Cancer Xenografts and Efficacy Evaluation Using 18F-FDG MicroPET-CT. Hum. Gene Ther. 2019, 30, 882-892. [CrossRef]

96. Hay, N. Reprogramming glucose metabolism in cancer: Can it be exploited for cancer therapy? Nat. Rev. Cancer 2016, 16, 635. [CrossRef]

97. Hamanaka, R.B.; Chandel, N.S. Targeting glucose metabolism for cancer therapy. J. Exp. Med. 2012, 209, 211-215. [CrossRef]

98. Yoshikawa, H.; Matsubara, K.; Qian, G.-S.; Jackson, P.; Groopman, J.D.; Manning, J.E.; Harris, C.C.; Herman, J.G. SOCS-1, a negative regulator of the JAK/STAT pathway, is silenced by methylation in human hepatocellular carcinoma and shows growth-suppression activity. Nat. Genet. 2001, 28, 29-35. [CrossRef]

99. Oshimo, Y.; Kuraoka, K.; Nakayama, H.; Kitadai, Y.; Yoshida, K.; Chayama, K.; Yasui, W. Epigenetic inactivation of SOCS-1 by CpG island hypermethylation in human gastric carcinoma. Int. J. Cancer 2004, 112, 1003-1009. [CrossRef]

100. Chen, C.Y.; Tsay, W.; Tang, J.L.; Shen, H.L.; Lin, S.W.; Huang, S.Y.; Yao, M.; Chen, Y.C.; Shen, M.C.; Wang, C.H. SOCS1 methylation in patients with newly diagnosed acute myeloid leukemia. Genes Chromosomes Cancer 2003, 37, 300-305. [CrossRef] [PubMed]

101. Liau, N.P.; Laktyushin, A.; Lucet, I.S.; Murphy, J.M.; Yao, S.; Whitlock, E.; Callaghan, K.; Nicola, N.A.; Kershaw, N.J.; Babon, J.J. The molecular basis of JAK/STAT inhibition by SOCS1. Nat. Commun. 2018, 9, 1-14. [CrossRef]

102. Danial, N.N.; Rothman, P. JAK-STAT signaling activated by Abl oncogenes. Oncogene 2000, 19, $2523-2531$. [CrossRef]

103. Jin, S.; Borkhuu, O.; Bao, W.; Yang, Y.-T. Signaling pathways in thyroid cancer and their therapeutic implications. J. Clin. Med. Res. 2016, 8, 284. [CrossRef]

104. Braun, J.; Hoang-Vu, C.; Dralle, H.; Hüttelmaier, S. Downregulation of microRNAs directs the EMT and invasive potential of anaplastic thyroid carcinomas. Oncogene 2010, 29, 4237-4244. [CrossRef] [PubMed]

105. Cifuentes-Rojas, C.; Hernandez, A.J.; Sarma, K.; Lee, J.T. Regulatory interactions between RNA and polycomb repressive complex 2. Mol. Cell 2014, 55, 171-185. [CrossRef]

106. Guil, S.; Soler, M.; Portela, A.; Carrère, J.; Fonalleras, E.; Gómez, A.; Villanueva, A.; Esteller, M. Intronic RNAs mediate EZH2 regulation of epigenetic targets. Nat. Struct. Mol. Biol. 2012, 19, 664. [CrossRef]

107. Mohammad, F.; Mondal, T.; Guseva, N.; Pandey, G.K.; Kanduri, C. Kcnq1ot1 noncoding RNA mediates transcriptional gene silencing by interacting with Dnmt1. Development 2010, 137, 2493-2499. [CrossRef]

108. Merry, C.R.; Forrest, M.E.; Sabers, J.N.; Beard, L.; Gao, X.-H.; Hatzoglou, M.; Jackson, M.W.; Wang, Z.; Markowitz, S.D.; Khalil, A.M. DNMT1-associated long non-coding RNAs regulate global gene expression and DNA methylation in colon cancer. Hum. Mol. Genet. 2015, 24, 6240-6253. [CrossRef]

109. Arab, K.; Park, Y.J.; Lindroth, A.M.; Schäfer, A.; Oakes, C.; Weichenhan, D.; Lukanova, A.; Lundin, E.; Risch, A.; Meister, M. Long noncoding RNA TARID directs demethylation and activation of the tumor suppressor TCF21 via GADD45A. Mol. Cell 2014, 55, 604-614. [CrossRef]

110. Lister, N.; Shevchenko, G.; Walshe, J.L.; Groen, J.; Johnsson, P.; Vidarsdóttir, L.; Grander, D.; Ataide, S.F.; Morris, K.V. The molecular dynamics of long noncoding RNA control of transcription in PTEN and its pseudogene. Proc. Natl. Acad. Sci. USA 2017, 114, 9942-9947. [CrossRef] [PubMed] 
111. Tripathi, V.; Ellis, J.D.; Shen, Z.; Song, D.Y.; Pan, Q.; Watt, A.T.; Freier, S.M.; Bennett, C.F.; Sharma, A.; Bubulya, P.A. The nuclear-retained noncoding RNA MALAT1 regulates alternative splicing by modulating SR splicing factor phosphorylation. Mol. Cell 2010, 39, 925-938. [CrossRef]

112. Zeng, T.; Ni, H.; Yu, Y.; Zhang, M.; Wu, M.; Wang, Q.; Wang, L.; Xu, S.; Xu, Z.; Xu, C. BACE1-AS prevents BACE1 mRNA degradation through the sequestration of BACE1-targeting miRNAs. J. Chem. Neuroanat. 2019, 98, 87-96. [CrossRef]

113. Yoon, J.-H.; Abdelmohsen, K.; Srikantan, S.; Yang, X.; Martindale, J.L.; De, S.; Huarte, M.; Zhan, M.; Becker, K.G.; Gorospe, M. LincRNA-p21 suppresses target mRNA translation. Mol. Cell 2012, 47, 648-655. [CrossRef]

114. Peng, W.-X.; Koirala, P.; Mo, Y.-Y. Y. LncRNA-mediated regulation of cell signaling in cancer. Oncogene 2017, 36, 5661-5667. [CrossRef]

115. Spizzo, R.; Almeida, M.I.; Colombatti, A.; Calin, G.A. Long non-coding RNAs and cancer: A new frontier of translational research? Oncogene 2012, 31, 4577-4587. [CrossRef]

116. Chen, Y.; Li, Y.; Gao, H. Long noncoding RNA CASC9 promotes the proliferation and metastasis of papillary thyroid cancer via sponging miR-488-3p. Cancer Med. 2020, 9, 1830-1841. [CrossRef]

117. Zhong, Z.; Wu, Y.; Luo, J.; Hu, X.; Yuan, Z.; Li, G.; Wang, Y.; Yao, G.; Ge, X. Knockdown of long noncoding RNA DLX6-AS1 inhibits migration and invasion of thyroid cancer cells by upregulating UPF1. Eur. Rev. Med. Pharmacol. Sci. 2019, 23, 10867-10873. [PubMed]

118. Song, B.; Li, R.; Zuo, Z.; Tan, J.; Liu, L.; Ding, D.; Lu, Y.; Hou, D. LncRNA ENST00000539653 acts as an oncogenic factor via MAPK signalling in papillary thyroid cancer. BMC Cancer 2019, 19, 297. [CrossRef]

119. Zhang, H.; Yu, Y.; Zhang, K.; Liu, X.; Dai, Y.; Jiao, X. Targeted inhibition of long non-coding RNA H19 blocks anaplastic thyroid carcinoma growth and metastasis. Bioengineered 2019, 10, 306-315. [CrossRef]

120. Li, M.; Chai, H.-F.; Peng, F.; Meng, Y.-T.; Zhang, L.-Z.; Zhang, L.; Zou, H.; Liang, Q.-L.; Li, M.-M.; Mao, K.-G. Estrogen receptor $\beta$ upregulated by lncRNA-H19 to promote cancer stem-like properties in papillary thyroid carcinoma. Cell Death Dis. 2018, 9, 1-15. [CrossRef]

121. Liang, L.; Xu, J.; Wang, M.; Xu, G.; Zhang, N.; Wang, G.; Zhao, Y. LncRNA HCP5 promotes follicular thyroid carcinoma progression via miRNAs sponge. Cell Death Dis. 2018, 9, 1-13. [CrossRef]

122. Dai, Y.; Miao, Y.; Zhu, Q.; Gao, M.; Hao, F. Expression of long non-coding RNA H19 predicts distant metastasis in minimally invasive follicular thyroid carcinoma. Bioengineered 2019, 10, 383-389. [CrossRef] [PubMed]

123. Sun, Z.; Guo, X.; Zang, M.; Wang, P.; Xue, S.; Chen, G. Long non-coding RNA LINC00152 promotes cell growth and invasion of papillary thyroid carcinoma by regulating the miR-497/BDNF axis. J. Cell. Physiol. 2019, 234, 1336-1345. [CrossRef]

124. Li, X.; Zhong, W.; Xu, Y.; Yu, B.; Liu, H. Silencing of lncRNA LINC00514 inhibits the malignant behaviors of papillary thyroid cancer through miR-204-3p/CDC23 axis. Biochem. Biophys. Res. Commun. 2019, 508, 1145-1148. [CrossRef]

125. Gugnoni, M.; Manicardi, V.; Torricelli, F.; Sauta, E.; Bellazzi, R.; Manzotti, G.; Vitale, E.; de Biase, D.; Piana, S.; Ciarrocchi, A. Linc00941 is a novel TGF $\beta$ target that primes papillary thyroid cancer metastatic behavior by regulating the expression of Cadherin 6. Thyroid 2020. [CrossRef]

126. Liu, J.; Dong, H.; Yang, Y.; Qian, Y.; Liu, J.; Li, Z.; Guan, H.; Chen, Z.; Li, C.; Zhang, K. Upregulation of long noncoding RNA MALAT1 in papillary thyroid cancer and its diagnostic value. Future Oncol. 2018, 14, 3015-3022. [CrossRef] [PubMed]

127. Wang, Y.; Bhandari, A.; Niu, J.; Yang, F.; Xia, E.; Yao, Z.; Jin, Y.; Zheng, Z.; Lv, S.; Wang, O. The lncRNA UNC5B-AS1 promotes proliferation, migration, and invasion in papillary thyroid cancer cell lines. Hum. Cell 2019, 32, 334-342. [CrossRef]

128. Liu, H.; Deng, H.; Zhao, Y.; Li, C.; Liang, Y. LncRNA XIST/miR-34a axis modulates the cell proliferation and tumor growth of thyroid cancer through MET-PI3K-AKT signaling. J. Exp. Clin. Cancer Res. 2018, 37, 1-12. [CrossRef]

129. Jiao, X.; Lu, J.; Huang, Y.; Zhang, J.; Zhang, H.; Zhang, K. Long non-coding RNA H19 may be a marker for prediction of prognosis in the follow-up of patients with papillary thyroid cancer. Cancer Biomark. 2019, 26, 203-207. [CrossRef] [PubMed]

130. Min, X.; Liu, K.; Zhu, H.; Zhang, J. Long noncoding RNA LINC003121 inhibits proliferation and invasion of thyroid cancer cells by suppression of the phosphatidylinositol-3-kinase (PI3K)/Akt signaling pathway. Med. Sci. Monit. Int. Med. J. Exp. Clin. Res. 2018, 24, 4592. [CrossRef] 
131. Pellecchia, S.; Sepe, R.; Decaussin-Petrucci, M.; Ivan, C.; Shimizu, M.; Coppola, C.; Testa, D.; Calin, G.A.; Fusco, A.; Pallante, P. The long non-coding RNA prader willi/angelman region RNA5 (PAR5) is downregulated in anaplastic thyroid carcinomas where it acts as a tumor suppressor by reducing EZH2 activity. Cancers 2020, 12, 235. [CrossRef]

132. Wang, X.-M.; Liu, Y.; Fan, Y.-X.; Liu, Z.; Yuan, Q.-L.; Jia, M.; Geng, Z.-S.; Gu, L.; Lu, X.-B. LncRNA PTCSC3 affects drug resistance of anaplastic thyroid cancer through STAT3/INO80 pathway. Cancer Biol. Ther. 2018, 19, 590-597. [CrossRef]

133. Duan, Y.; Wang, Z.; Xu, L.; Sun, L.; Song, H.; Yin, H.; He, F. IncRNA SNHG3 acts as a novel Tumor Suppressor and regulates Tumor Proliferation and Metastasis via AKT/mTOR/ERK pathway in Papillary Thyroid Carcinoma. J. Cancer 2020, 11, 3492. [CrossRef] [PubMed]

134. Lv, M.; Zhong, Z.; Huang, M.; Tian, Q.; Jiang, R.; Chen, J. lncRNA H19 regulates epithelial-mesenchymal transition and metastasis of bladder cancer by miR-29b-3p as competing endogenous RNA. Biochim. Biophys. Acta Mol. Cell Res. 2017, 1864, 1887-1899. [CrossRef]

135. Zhou, W.; Ye, X.-L.; Xu, J.; Cao, M.-G.; Fang, Z.-Y.; Li, L.-Y.; Guan, G.-H.; Liu, Q.; Qian, Y.-H.; Xie, D. The lncRNA H19 mediates breast cancer cell plasticity during EMT and MET plasticity by differentially sponging miR-200b/c and let-7b. Sci. Signal. 2017, 10, eaak9557. [CrossRef]

136. Peng, F.; Li, T.-T.; Wang, K.-L.; Xiao, G.-Q.; Wang, J.-H.; Zhao, H.-D.; Kang, Z.-J.; Fan, W.-J.; Zhu, L.-L.; Li, M. H19/let-7/LIN28 reciprocal negative regulatory circuit promotes breast cancer stem cell maintenance. Cell Death Dis. 2018, 8, e2569. [CrossRef]

137. Vernucci, M.; Cerrato, F.; Besnard, N.; Casola, S.; Pedone, P.V.; Bruni, C.B.; Riccio, A. The H19 endodermal enhancer is required for Igf2 activation and tumor formation in experimental liver carcinogenesis. Oncogene 2000, 19, 6376-6385. [CrossRef]

138. Liu, W.; Xu, Q. Upregulation of circHIPK3 promotes the progression of gastric cancer via Wnt/beta-catenin pathway and indicates a poor prognosis. Eur. Rev. Med. Pharm. Sci. 2019, 23, 7905-7912.

139. Shen, Z.; Zhou, L.; Zhang, C.; Xu, J. Reduction of circular RNA Foxo3 promotes prostate cancer progression and chemoresistance to docetaxel. Cancer Lett. 2020, 468, 88-101. [CrossRef]

140. Sun, Y.; Li, X.; Chen, A.; Shi, W.; Wang, L.; Yi, R.; Qiu, J. circPIP5K1A serves as a competitive endogenous RNA contributing to ovarian cancer progression via regulation of miR-661/IGFBP5 signaling. J. Cell. Biochem. 2019, 120, 19406-19414. [CrossRef]

141. Zhou, G.; Zhang, G.; Yuan, Z.; Pei, R.; Liu, D. Has_circ_0008274 promotes cell proliferation and invasion involving AMPK/mTOR signaling pathway in papillary thyroid carcinoma. Eur. Rev. Med. Pharm. Sci. 2018, $22,8772-8780$.

142. Liu, F.; Zhang, J.; Qin, L.; Yang, Z.; Xiong, J.; Zhang, Y.; Li, R.; Li, S.; Wang, H.; Yu, B. Circular RNA EIF6 (Hsa_circ_0060060) sponges miR-144-3p to promote the cisplatin-resistance of human thyroid carcinoma cells by autophagy regulation. Aging 2018, 10, 3806. [CrossRef]

143. Ye, M.; Hou, H.; Shen, M.; Dong, S.; Zhang, T. Circular RNA circFOXM1 plays a role in papillary thyroid carcinoma by sponging miR-1179 and regulating HMGB1 expression. Mol. Ther. Nucleic Acids 2020, 19, 741-750. [CrossRef]

144. Cork, G.K.; Thompson, J.; Slawson, C. Real talk: The inter-play between the mTOR, AMPK, and hexosamine biosynthetic pathways in cell signaling. Front. Endocrinol. 2018, 9, 522. [CrossRef] [PubMed]

145. Allinen, M.; Beroukhim, R.; Cai, L.; Brennan, C.; Lahti-Domenici, J.; Huang, H.; Porter, D.; Hu, M.; Chin, L.; Richardson, A. Molecular characterization of the tumor microenvironment in breast cancer. Cancer Cell 2004, 6, 17-32. [CrossRef]

146. Moroishi, T.; Hayashi, T.; Pan, W.-W.; Fujita, Y.; Holt, M.V.; Qin, J.; Carson, D.A.; Guan, K.-L. The Hippo pathway kinases LATS1/2 suppress cancer immunity. Cell 2016, 167, 1525-1539. [CrossRef]

147. Locati, M.; Mantovani, A.; Sica, A. Macrophage activation and polarization as an adaptive component of innate immunity. In Advances in Immunology; Elsevier: Amsterdam, The Netherlands, 2013; Volume 120, pp. 163-184.

148. Baer, C.; Squadrito, M.L.; Iruela-Arispe, M.L.; De Palma, M. Reciprocal interactions between endothelial cells and macrophages in angiogenic vascular niches. Exp. Cell Res. 2013, 319, 1626-1634. [CrossRef]

149. Chen, Y.; Song, Y.; Du, W.; Gong, L.; Chang, H.; Zou, Z. Tumor-associated macrophages: An accomplice in solid tumor progression. J. Biomed. Sci. 2019, 26, 1-13. [CrossRef] 
150. Adeegbe, D.O.; Nishikawa, H. Natural and induced T regulatory cells in cancer. Front. Immunol. 2013, 4, 190. [CrossRef]

151. Li, J.-H.; Zhang, S.-Q.; Qiu, X.-G.; Zhang, S.-J.; Zheng, S.-H.; Zhang, D.-H. Long non-coding RNA NEAT1 promotes malignant progression of thyroid carcinoma by regulating miRNA-214. Int. J. Oncol. 2017, 50, 708-716. [CrossRef]

152. Han, D.; Fang, Y.; Guo, Y.; Hong, W.; Tu, J.; Wei, W. The emerging role of long non-coding RNAs in tumor-associated macrophages. J. Cancer 2019, 10, 6738. [CrossRef]

153. Huang, J.K.; Ma, L.; Song, W.H.; Lu, B.Y.; Huang, Y.B.; Dong, H.M.; Ma, X.K.; Zhu, Z.Z.; Zhou, R. LncRNA-MALAT1 promotes angiogenesis of thyroid cancer by modulating tumor-associated macrophage FGF2 protein secretion. J. Cell. Biochem. 2017, 118, 4821-4830. [CrossRef]

154. Amit, M.; Rudnicki, Y.; Binenbaum, Y.; Trejo-Leider, L.; Cohen, J.T.; Gil, Z. Defining the outcome of patients with delayed diagnosis of differentiated thyroid cancer. Laryngoscope 2014, 124, 2837-2840. [CrossRef]

155. WHO. Guide to Cancer Early Diagnosis; World Health Organization: Geneva, Switzerland, 2017.

156. Cooper, D.S.; Doherty, G.M.; Haugen, B.R.; Kloos, R.T.; Lee, S.L.; Mandel, S.J.; Mazzaferri, E.L.; McIver, B.; Pacini, F.; Schlumberger, M. Revised American Thyroid Association management guidelines for patients with thyroid nodules and differentiated thyroid cancer: The American Thyroid Association (ATA) guidelines taskforce on thyroid nodules and differentiated thyroid cancer. Thyroid 2009, 19, 1167-1214. [CrossRef]

157. Sclabas, G.M.; Staerkel, G.A.; Shapiro, S.E.; Fornage, B.D.; Sherman, S.I.; Vassillopoulou-Sellin, R.; Lee, J.E.; Evans, D.B. Fine-needle aspiration of the thyroid and correlation with histopathology in a contemporary series of 240 patients. Am. J. Surg. 2003, 186, 702-710. [CrossRef]

158. Yang, J.; Schnadig, V.; Logrono, R.; Wasserman, P.G. Fine-needle aspiration of thyroid nodules: A study of 4703 patients with histologic and clinical correlations. Cancer Cytopathol. 2007, 111, 306-315. [CrossRef]

159. Cibas, E.S.; Ali, S.Z. The 2017 Bethesda system for reporting thyroid cytopathology. Thyroid 2017, 27, 1341-1346. [CrossRef]

160. Lum, J.N.M. Thyroid FNA: A retrospective audit of 1541 cases at NUH, Singapore. In Proceedings of the NUH Cytopathology Workshop 2014, Singapore, 23-25 May 2014; NUH: Singapore, 2014.

161. Sistrunk, J.; Alexander, S.; Marc, F.; Johnson, T.; Norman, F.; Philip, G.; Richard, G.; Edward, G. Clinical performance of multiplatform mutation panel microRNA risk classifier in indeterminate thyroid nodules. J. Am. Soc. Cytopathol. 2020, 9, 232-241. [CrossRef]

162. Albarel, F.; Conte-Devolx, B.; Oliver, C. From nodule to differentiated thyroid carcinoma: Contributions of molecular analysis in 2012. In Annales D'endocrinologie; Elsevier Masson: Paris, France; pp. 155-164.

163. Ferrari, S.M.; Fallahi, P.; Ruffilli, I.; Elia, G.; Ragusa, F.; Paparo, S.R.; Ulisse, S.; Baldini, E.; Giannini, R.; Miccoli, P. Molecular testing in the diagnosis of differentiated thyroid carcinomas. Gland Surg. 2018, 7, S19. [CrossRef] [PubMed]

164. Chakraborty, A.; Narkar, A.; Mukhopadhyaya, R.; Kane, S.; D’Cruz, A.; Rajan, M. BRAF V600E mutation in papillary thyroid carcinoma: Significant association with node metastases and extra thyroidal invasion. Endocr. Pathol. 2012, 23, 83-93. [CrossRef]

165. Guan, H.; Ji, M.; Bao, R.; Yu, H.; Wang, Y.; Hou, P.; Zhang, Y.; Shan, Z.; Teng, W.; Xing, M. Association of high iodine intake with the T1799A BRAF mutation in papillary thyroid cancer. J. Clin. Endocrinol. Metab. 2009, 94, 1612-1617. [CrossRef] [PubMed]

166. Jung, C.-K.; Im, S.-Y.; Kang, Y.-J.; Lee, H.; Jung, E.-S.; Kang, C.-S.; Bae, J.-S.; Choi, Y.-J. Mutational patterns and novel mutations of the BRAF gene in a large cohort of Korean patients with papillary thyroid carcinoma. Thyroid 2012, 22, 791-797. [CrossRef]

167. Network, C.G.A.R. Integrated genomic characterization of papillary thyroid carcinoma. Cell 2014, 159, 676-690.

168. Romei, C.; Fugazzola, L.; Puxeddu, E.; Frasca, F.; Viola, D.; Muzza, M.; Moretti, S.; Luisa Nicolosi, M.; Giani, C.; Cirello, V. Modifications in the papillary thyroid cancer gene profile over the last 15 years. J. Clin. Endocrinol. Metab. 2012, 97, E1758-E1765. [CrossRef]

169. Goh, X.; Lum, J.; Yang, S.P.; Chionh, S.B.; Koay, E.; Chiu, L.; Parameswaran, R.; Ngiam, K.Y.; Loh, T.K.S.; Nga, M.E. BRAF mutation in papillary thyroid cancer-Prevalence and clinical correlation in a South-East Asian cohort. Clin. Otolaryngol. 2019, 44, 114-123. [CrossRef] 
170. Arita, T.; Ichikawa, D.; Konishi, H.; Komatsu, S.; Shiozaki, A.; Shoda, K.; Kawaguchi, T.; Hirajima, S.; Nagata, H.; Kubota, T. Circulating long non-coding RNAs in plasma of patients with gastric cancer. Anticancer Res. 2013, 33, 3185-3193.

171. Chen, X.; Ba, Y.; Ma, L.; Cai, X.; Yin, Y.; Wang, K.; Guo, J.; Zhang, Y.; Chen, J.; Guo, X. Characterization of microRNAs in serum: A novel class of biomarkers for diagnosis of cancer and other diseases. Cell Res. 2008, 18, 997-1006. [CrossRef] [PubMed]

172. Ferracin, M.; Veronese, A.; Negrini, M. Micromarkers: MiRNAs in cancer diagnosis and prognosis. Expert Rev. Mol. Diagn. 2010, 10, 297-308. [CrossRef] [PubMed]

173. Huang, Z.; Zhu, D.; Wu, L.; He, M.; Zhou, X.; Zhang, L.; Zhang, H.; Wang, W.; Zhu, J.; Cheng, W. Six serum-based miRNAs as potential diagnostic biomarkers for gastric cancer. Cancer Epidemiol. Prev. Biomark. 2017, 26, 188-196. [CrossRef]

174. Sartori, D.A.; Chan, D.W. Biomarkers in prostate cancer: What's new? Curr. Opin. Oncol. 2014, $26,259$. [CrossRef]

175. Labourier, E.; Shifrin, A.; Busseniers, A.E.; Lupo, M.A.; Manganelli, M.L.; Andruss, B.; Wylie, D.; Beaudenon-Huibregtse, S. Molecular testing for miRNA, mRNA, and DNA on fine-needle aspiration improves the preoperative diagnosis of thyroid nodules with indeterminate cytology. J. Clin. Endocrinol. Metab. 2015, 100, 2743-2750. [CrossRef]

176. Yang, F.; Zhang, H.; Leng, X.; Hao, F.; Wang, L. miR-146b measurement in FNA to distinguish papillary thyroid cancer from benign thyroid masses. Br. J. Biomed. Sci. 2018, 75, 43-45. [CrossRef]

177. Zhang, A.; Wang, C.; Lu, H.; Chen, X.; Ba, Y.; Zhang, C.; Zhang, C.-Y. Altered Serum MicroRNA Profile May Serve as an Auxiliary Tool for Discriminating Aggressive Thyroid Carcinoma from Nonaggressive Thyroid Cancer and Benign Thyroid Nodules. Dis. Markers 2019, 2019, 3717683. [CrossRef] [PubMed]

178. Rosignolo, F.; Sponziello, M.; Giacomelli, L.; Russo, D.; Pecce, V.; Biffoni, M.; Bellantone, R.; Lombardi, C.P.; Lamartina, L.; Grani, G. Identification of thyroid-associated serum microRNA profiles and their potential use in thyroid cancer follow-up. J. Endocr. Soc. 2017, 1, 3-13.

179. Zhang, Y.; Pan, J.; Xu, D.; Yang, Z.; Sun, J.; Sun, L.; Wu, Y.; Qiao, H. Combination of serum microRNAs and ultrasound profile as predictive biomarkers of diagnosis and prognosis for papillary thyroid microcarcinoma. Oncol. Rep. 2018, 40, 3611-3624. [CrossRef]

180. Graham, M.E.R.; Hart, R.D.; Douglas, S.; Makki, F.M.; Pinto, D.; Butler, A.L.; Bullock, M.; Rigby, M.H.; Trites, J.R.; Taylor, S.M. Serum microRNA profiling to distinguish papillary thyroid cancer from benign thyroid masses. J. Otolaryngol. Head Neck Surg. 2015, 44, 33. [CrossRef]

181. Ye, W.; Deng, X.; Fan, Y. Exosomal miRNA423-5p mediated oncogene activity in papillary thyroid carcinoma: A potential diagnostic and biological target for cancer therapy. Neoplasma 2019, 66, 516-523. [CrossRef]

182. Bonneau, E.; Neveu, B.; Kostantin, E.; Tsongalis, G.; De Guire, V. How close are miRNAs from clinical practice? A perspective on the diagnostic and therapeutic market. Ejifcc 2019, 30, 114.

183. Jackson, S.; Kumar, G.; Banizs, A.B.; Toney, N.; Silverman, J.F.; Narick, C.M.; Finkelstein, S.D. Incremental utility of expanded mutation panel when used in combination with microRNA classification in indeterminate thyroid nodules. Diagn. Cytopathol. 2020, 48, 43-52. [CrossRef] [PubMed]

184. Sistrunk, J.W.; Shifrin, A.; Frager, M.; Bardales, R.H.; Thomas, J.; Fishman, N.; Goldberg, P.; Guttler, R.; Grant, E. Clinical impact of testing for mutations and microRNAs in thyroid nodules. Diagn. Cytopathol. 2019, 47, 758-764. [CrossRef]

185. Schlosser, K.; Hanson, J.; Villeneuve, P.J.; Dimitroulakos, J.; McIntyre, L.; Pilote, L.; Stewart, D.J. Assessment of circulating LncRNAs under physiologic and pathologic conditions in humans reveals potential limitations as biomarkers. Sci. Rep. 2016, 6, 36596. [CrossRef]

186. Xu, W.; Zhou, G.; Wang, H.; Liu, Y.; Chen, B.; Chen, W.; Lin, C.; Wu, S.; Gong, A.; Xu, M. Circulating lncRNA SNHG11 as a novel biomarker for early diagnosis and prognosis of colorectal cancer. Int. J. Cancer 2020, 146, 2901-2912. [CrossRef] [PubMed]

187. Wang, L.; Duan, W.; Yan, S.; Xie, Y.; Wang, C. Circulating long non-coding RNA colon cancer-associated transcript 2 protected by exosome as a potential biomarker for colorectal cancer. Biomed. Pharmacother. 2019, 113, 108758. [CrossRef]

188. Abedini, P.; Fattahi, A.; Agah, S.; Talebi, A.; Beygi, A.H.; Amini, S.M.; Mirzaei, A.; Akbari, A. Expression analysis of circulating plasma long noncoding RNAs in colorectal cancer: The relevance of lncRNAs ATB and CCAT1 as potential clinical hallmarks. J. Cell. Physiol. 2019, 234, 22028-22033. [CrossRef] 
189. Özgür, E.; Ferhatoğlu, F.; Şen, F.; Saip, P.; Gezer, U. Circulating lncRNA H19 may be a useful marker of response to neoadjuvant chemotherapy in breast cancer. Cancer Biomark. 2020, 27, 11-17. [CrossRef]

190. Liu, Y.; Feng, W.; Liu, W.; Kong, X.; Li, L.; He, J.; Wang, D.; Zhang, M.; Zhou, G.; Xu, W. Circulating IncRNA ABHD11-AS1 serves as a biomarker for early pancreatic cancer diagnosis. J. Cancer 2019, 10, 3746. [CrossRef]

191. Yu, J.; Ding, W.B.; Wang, M.C.; Guo, X.G.; Xu, J.; Xu, Q.G.; Yang, Y.; Sun, S.H.; Liu, J.F.; Qin, L.X. Plasma circular RNA panel to diagnose hepatitis B virus-related hepatocellular carcinoma: A large-scale, multicenter study. Int. J. Cancer 2020, 146, 1754-1763. [CrossRef] [PubMed]

192. Zhao, S.-Y.; Wang, J.; Ouyang, S.-B.; Huang, Z.-K.; Liao, L. Salivary circular RNAs Hsa_Circ_0001874 and Hsa_Circ_0001971 as novel biomarkers for the diagnosis of Oral squamous cell carcinoma. Cell. Physiol. Biochem. 2018, 47, 2511-2521. [CrossRef]

193. Liu, Y.-T.; Han, X.-H.; Xing, P.-Y.; Hu, X.-S.; Hao, X.-Z.; Wang, Y.; Li, J.-L.; Zhang, Z.-S.; Yang, Z.-H.; Shi, Y.-K. Circular RNA profiling identified as a biomarker for predicting the efficacy of gefitinib therapy for non-small cell lung cancer. J. Thorac. Dis. 2019, 11, 1779. [CrossRef]

194. Ortholan, C.; Puissegur, M.-P.; Ilie, M.; Barbry, P.; Mari, B.; Hofman, P. MicroRNAs and lung cancer: New oncogenes and tumor suppressors, new prognostic factors and potential therapeutic targets. Curr. Med. Chem. 2009, 16, 1047-1061. [CrossRef]

195. Huang, X.; Yuan, T.; Liang, M.; Du, M.; Xia, S.; Dittmar, R.; Wang, D.; See, W.; Costello, B.A.; Quevedo, F. Exosomal miR-1290 and miR-375 as prognostic markers in castration-resistant prostate cancer. Eur. Urol. 2015, 67, 33-41. [CrossRef]

196. Takamizawa, J.; Konishi, H.; Yanagisawa, K.; Tomida, S.; Osada, H.; Endoh, H.; Harano, T.; Yatabe, Y.; Nagino, M.; Nimura, Y. Reduced expression of the let-7 microRNAs in human lung cancers in association with shortened postoperative survival. Cancer Res. 2004, 64, 3753-3756. [CrossRef]

197. Hu, Y.; Tian, H.; Xu, J.; Fang, J.-Y. Roles of competing endogenous RNAs in gastric cancer. Brief. Funct. Genom. 2016, 15, 266-273. [CrossRef]

198. Donghi, R.; Longoni, A.; Pilotti, S.; Michieli, P.; Della Porta, G.; Pierotti, M.A. Gene p53 mutations are restricted to poorly differentiated and undifferentiated carcinomas of the thyroid gland. J. Clin. Investig. 1993, 91, 1753-1760. [CrossRef]

199. Handkiewicz-Junak, D.; Czarniecka, A.; Jarząb, B. Molecular prognostic markers in papillary and follicular thyroid cancer: Current status and future directions. Mol. Cell. Endocrinol. 2010, 322, 8-28. [CrossRef]

200. Passler, C.; Scheuba, C.; Prager, G.; Kaczirek, K.; Kaserer, K.; Zettinig, G.; Niederle, B. Prognostic factors of papillary and follicular thyroid cancer: Differences in an iodine-replete endemic goiter region. Endocr. Relat. Cancer 2004, 11, 131-139. [CrossRef] [PubMed]

201. Sondermann, A.; Andreghetto, F.M.; Moulatlet, A.C.B.; da Silva Victor, E.; de Castro, M.G.; Nunes, F.D.; Brandão, L.G.; Severino, P. MiR-9 and miR-21 as prognostic biomarkers for recurrence in papillary thyroid cancer. Clin. Exp. Metastasis 2015, 32, 521-530. [CrossRef]

202. Dai, L.; Wang, Y.; Chen, L.; Zheng, J.; Li, J.; Wu, X. MiR-221, a potential prognostic biomarker for recurrence in papillary thyroid cancer. World J. Surg. Oncol. 2017, 15, 11. [CrossRef]

203. Geraldo, M.V.; Nakaya, H.I.; Kimura, E.T. Down-regulation of 14q32-encoded miRNAs and tumor suppressor role for miR-654-3p in papillary thyroid cancer. Oncotarget 2017, 8, 9597. [CrossRef]

204. Haghpanah, V.; Fallah, P.; Tavakoli, R.; Naderi, M.; Samimi, H.; Soleimani, M.; Larijani, B. Antisense-miR-21 enhances differentiation/apoptosis and reduces cancer stemness state on anaplastic thyroid cancer. Tumor Biol. 2016, 37, 1299-1308. [CrossRef]

205. Frezzetti, D.; De Menna, M.; Zoppoli, P.; Guerra, C.; Ferraro, A.; Bello, A.; De Luca, P.; Calabrese, C.; Fusco, A.; Ceccarelli, M. Upregulation of miR-21 by Ras in vivo and its role in tumor growth. Oncogene 2011, 30, 275-286. [CrossRef]

206. Pennelli, G.; Galuppini, F.; Barollo, S.; Cavedon, E.; Bertazza, L.; Fassan, M.; Guzzardo, V.; Pelizzo, M.R.; Rugge, M.; Mian, C. The PDCD4/miR-21 pathway in medullary thyroid carcinoma. Hum. Pathol. 2015, 46, 50-57. [CrossRef]

207. Durante, C.; Haddy, N.; Baudin, E.; Leboulleux, S.; Hartl, D.; Travagli, J.; Caillou, B.; Ricard, M.; Lumbroso, J.; De Vathaire, F. Long-term outcome of 444 patients with distant metastases from papillary and follicular thyroid carcinoma: Benefits and limits of radioiodine therapy. J. Clin. Endocrinol. Metab. 2006, 91, 2892-2899. [CrossRef] 
208. Schlumberger, M.; Tubiana, M.; Florent De, V.; Hill, C.; Paule, G.; Jean-Paul, T.; Philippe, F.; Jean, L.; Bernard, C.; Claude, P. Long-term results of treatment of 283 patients with lung and bone metastases from differentiated thyroid carcinoma. J. Clin. Endocrinol. Metab. 1986, 63, 960-967.

209. Buffet, C.; Wassermann, J.; Hecht, F.; Leenhardt, L.; Dupuy, C.; Groussin, L.; Lussey-Lepoutre, C. Redifferentiation of radioiodine-refractory thyroid cancers. Endocr. Relat. Cancer 2020, 27, R113-R132. [CrossRef]

210. Riesco-Eizaguirre, G.; Rodríguez, I.; De la Vieja, A.; Costamagna, E.; Carrasco, N.; Nistal, M.; Santisteban, P. The BRAFV600E oncogene induces transforming growth factor $\beta$ secretion leading to sodium iodide symporter repression and increased malignancy in thyroid cancer. Cancer Res. 2009, 69, 8317-8325. [CrossRef] [PubMed]

211. Lakshmanan, A.; Scarberry, D.; Green, J.A.; Zhang, X.; Selmi-Ruby, S.; Jhiang, S.M. Modulation of thyroidal radioiodide uptake by oncological pipeline inhibitors and Apigenin. Oncotarget 2015, 6, 31792. [CrossRef]

212. Pak, K.; Shin, S.; Kim, S.-J.; Kim, I.-J.; Chang, S.; Koo, P.; Kwak, J.; Kim, J.-H. Response of retinoic acid in patients with radioactive iodine-refractory thyroid Cancer: A meta-analysis. Oncol. Res. Treat. 2018, 41, 100-104. [CrossRef]

213. Fu, H.; Cheng, L.; Jin, Y.; Cheng, L.; Liu, M.; Chen, L. MAPK Inhibitors Enhance HDAC Inhibitor-Induced Redifferentiation in Papillary Thyroid Cancer Cells Harboring BRAFV600E: An In Vitro Study. Mol. Ther. Oncolytics 2019, 12, 235-245. [CrossRef]

214. Rosenbaum-Krumme, S.J.; Freudenberg, L.S.; Jentzen, W.; Bockisch, A.; Nagarajah, J. Effects of rosiglitazone on radioiodine negative and progressive differentiated thyroid carcinoma as assessed by 124I PET/CT imaging. Clin. Nucl. Med. 2012, 37, e47-e52. [CrossRef]

215. Li, L.; Lv, B.; Chen, B.; Guan, M.; Sun, Y.; Li, H.; Zhang, B.; Ding, C.; He, S.; Zeng, Q. Inhibition of miR-146b expression increases radioiodine-sensitivity in poorly differential thyroid carcinoma via positively regulating NIS expression. Biochem. Biophys. Res. Commun. 2015, 462, 314-321. [CrossRef] [PubMed]

216. Riesco-Eizaguirre, G.; Wert-Lamas, L.; Perales-Patón, J.; Sastre-Perona, A.; Fernández, L.P.; Santisteban, P. The miR-146b-3p/PAX8/NIS regulatory circuit modulates the differentiation phenotype and function of thyroid cells during carcinogenesis. Cancer Res. 2015, 75, 4119-4130. [CrossRef] [PubMed]

217. Damanakis, A.I.; Eckhardt, S.; Wunderlich, A.; Roth, S.; Wissniowski, T.T.; Bartsch, D.K.; Di Fazio, P. MicroRNAs let7 expression in thyroid cancer: Correlation with their deputed targets HMGA2 and SLC5A5. J. Cancer Res. Clin. Oncol. 2016, 142, 1213-1220. [CrossRef]

218. Sahin Lacin, E.E.; Karakas, Y.; Yalcin, S. Metastatic medullary thyroid cancer: A dramatic response to a systemic chemotherapy (temozolomide and capecitabine) regimen. Oncotargets Ther. 2015, 8, 1039.

219. Chu, E.; Sartorelli, A. Cancer chemotherapy. Basic Clin. Pharmacol. 2004, 10, 878-907.

220. Stein, R.; Chen, S.; Reed, L.; Richel, H.; Goldenberg, D.M. Combining radioimmunotherapy and chemotherapy for treatment of medullary thyroid carcinoma: Effectiveness of dacarbazine. Cancer 2002, 94, 51-61. [CrossRef]

221. Wilson, P.; Millar, B.; Brierley, J. The management of advanced thyroid cancer. Clin. Oncol. 2004, 16, 561-568. [CrossRef] [PubMed]

222. Lessin, L.S.; Min, M. Chemotherapy for thyroid cancer. In Thyroid Cancer; Springer: Berlin/Heidelberg, Germany, 2000; pp. 179-182.

223. Gottlieb, J.A.; Hill, C.S., Jr. Chemotherapy of thyroid cancer with adriamycin: Experience with 30 patients. New Engl. J. Med. 1974, 290, 193-197. [CrossRef] [PubMed]

224. Brose, M.S.; Nutting, C.M.; Jarzab, B.; Elisei, R.; Siena, S.; Bastholt, L.; De La Fouchardiere, C.; Pacini, F.; Paschke, R.; Shong, Y.K. Sorafenib in radioactive iodine-refractory, locally advanced or metastatic differentiated thyroid cancer: A randomised, double-blind, phase 3 trial. Lancet 2014, 384, 319-328. [CrossRef]

225. Schlumberger, M.; Tahara, M.; Wirth, L.J.; Robinson, B.; Brose, M.S.; Elisei, R.; Habra, M.A.; Newbold, K.; Shah, M.H.; Hoff, A.O. Lenvatinib versus placebo in radioiodine-refractory thyroid cancer. New Engl. J. Med. 2015, 372, 621-630. [CrossRef]

226. Gianoukakis, A.G.; Dutcus, C.E.; Batty, N.; Guo, M.; Baig, M. Prolonged duration of response in lenvatinib responders with thyroid cancer. Endocr. Relat. Cancer 2018, 25, 699-704. [CrossRef]

227. Wells, S.A., Jr.; Robinson, B.G.; Gagel, R.F.; Dralle, H.; Fagin, J.A.; Santoro, M.; Baudin, E.; Elisei, R.; Jarzab, B.; Vasselli, J.R. Vandetanib in patients with locally advanced or metastatic medullary thyroid cancer: A randomized, double-blind phase III trial. J. Clin. Oncol. 2012, 30, 134. [CrossRef] 
228. Schlumberger, M.; Elisei, R.; Müller, S.; Schöffski, P.; Brose, M.S.; Shah, M.H.; Licitra, L.F.; Jarzab, B.; Medvedev, V.; Kreissl, M. Final overall survival analysis of EXAM, an international, double-blind, randomized, placebo-controlled phase III trial of cabozantinib (Cabo) in medullary thyroid carcinoma (MTC) patients with documented RECIST progression at baseline. Am. Soc. Clin. Oncol. 2015. [CrossRef]

229. Subbiah, V.; Kreitman, R.J.; Wainberg, Z.A.; Cho, J.Y.; Schellens, J.H.; Soria, J.C.; Wen, P.Y.; Zielinski, C.; Cabanillas, M.E.; Urbanowitz, G. Dabrafenib and trametinib treatment in patients with locally advanced or metastatic BRAF V600-mutant anaplastic thyroid cancer. J. Clin. Oncol. 2018, 36, 7. [CrossRef]

230. Hong, D.S.; DuBois, S.G.; Kummar, S.; Farago, A.F.; Albert, C.M.; Rohrberg, K.S.; van Tilburg, C.M.; Nagasubramanian, R.; Berlin, J.D.; Federman, N. Larotrectinib in patients with TRK fusion-positive solid tumours: A pooled analysis of three phase 1/2 clinical trials. Lancet Oncol. 2020, 21, 531-540. [CrossRef]

231. Doebele, R.C.; Drilon, A.; Paz-Ares, L.; Siena, S.; Shaw, A.T.; Farago, A.F.; Blakely, C.M.; Seto, T.; Cho, B.C.; Tosi, D. Entrectinib in patients with advanced or metastatic NTRK fusion-positive solid tumours: Integrated analysis of three phase 1-2 trials. Lancet Oncol. 2020, 21, 271-282. [CrossRef]

232. Robbins, R.J.; Srivastava, S.; Shaha, A.; Ghossein, R.; Larson, S.M.; Fleisher, M.; Tuttle, R.M. Factors influencing the basal and recombinant human thyrotropin-stimulated serum thyroglobulin in patients with metastatic thyroid carcinoma. J. Clin. Endocrinol. Metab. 2004, 89, 6010-6016. [CrossRef]

233. Schlumberger, M.; Hitzel, A.; Toubert, M.; Corone, C.; Troalen, F.; Schlageter, M.; Claustrat, F.; Koscielny, S.; Taieb, D.; Toubeau, M. Comparison of seven serum thyroglobulin assays in the follow-up of papillary and follicular thyroid cancer patients. J. Clin. Endocrinol. Metab. 2007, 92, 2487-2495. [CrossRef]

234. Spencer, C.A. Clinical utility of thyroglobulin antibody $(\mathrm{Tg} \mathrm{Ab})$ measurements for patients with differentiated thyroid cancers (DTC). J. Clin. Endocrinol. Metab. 2011, 96, 3615-3627. [CrossRef]

235. Giovanella, L.; Suriano, S.; Ceriani, L.; Verburg, F.A. Undetectable Thyroglobulin in Patients with Differentiated Thyroid Carcinoma and Residual Radioiodine Uptake on a Postablation Whole-Body Scan. Clin. Nucl. Med. 2011, 36, 109-112. [CrossRef]

236. Diesch, J.; Zwick, A.; Garz, A.-K.; Palau, A.; Buschbeck, M.; Götze, K.S. A clinical-molecular update on azanucleoside-based therapy for the treatment of hematologic cancers. Clin. Epigenetics 2016, 8, 71. [CrossRef]

237. Bainschab, A.; Quehenberger, F.; Greinix, H.T.; Krause, R.; Wölfler, A.; Sill, H.; Zebisch, A. Infections in patients with acute myeloid leukemia treated with low-intensity therapeutic regimens: Risk factors and efficacy of antibiotic prophylaxis. Leuk. Res. 2016, 42, 47-51. [CrossRef] [PubMed]

238. Slaby, O.; Laga, R.; Sedlacek, O. Therapeutic targeting of non-coding RNAs in cancer. Biochem. J. 2017, 474, 4219-4251. [CrossRef]

239. Wang, W.-T.; Han, C.; Sun, Y.-M.; Chen, T.-Q.; Chen, Y.-Q. Noncoding RNAs in cancer therapy resistance and targeted drug development. J. Hematol. Oncol. 2019, 12, 55. [CrossRef]

240. Xu, Y.; Han, Y.F.; Ye, B.; Zhang, Y.L.; Dong, J.D.; Zhu, S.J.; Chen, J. miR-27b-3p is Involved in Doxorubicin Resistance of Human Anaplastic Thyroid Cancer Cells via Targeting Peroxisome Proliferator-Activated Receptor Gamma. Basic Clin. Pharmacol. Toxicol. 2018, 123, 670-677. [CrossRef]

241. Liu, Y.; Yue, P.; Zhou, T.; Zhang, F.; Wang, H.; Chen, X. LncRNA MEG3 enhances 131I sensitivity in thyroid carcinoma via sponging miR-182. Biomed. Pharmacother. 2018, 105, 1232-1239. [CrossRef] [PubMed]

242. Liu, C.; Feng, Z.; Chen, T.; Lv, J.; Liu, P.; Jia, L.; Zhu, J.; Chen, F.; Yang, C.; Deng, Z. Downregulation of NEAT1 reverses the radioactive iodine resistance of papillary thyroid carcinoma cell via miR-101-3p/FN1/PI3K-AKT signaling pathway. Cell Cycle 2019, 18, 167-203. [CrossRef]

243. Xiang, C.; Zhang, M.-L.; Zhao, Q.-Z.; Xie, Q.-P.; Yan, H.-C.; Yu, X.; Wang, P.; Wang, Y. LncRNA-SLC6A9-5: 2: A potent sensitizer in 131I-resistant papillary thyroid carcinoma with PARP-1 induction. Oncotarget 2017, 8, 22954. [CrossRef]

244. Tan, H.-L.; Chan, K.-G.; Pusparajah, P.; Saokaew, S.; Duangjai, A.; Lee, L.-H.; Goh, B.-H. Anti-cancer properties of the naturally occurring aphrodisiacs: Icariin and its derivatives. Front. Pharmacol. 2016, 7, 191. [CrossRef] [PubMed]

245. Li, J.; Jiang, K.; Zhao, F. Icariin regulates the proliferation and apoptosis of human ovarian cancer cells through microRNA-21 by targeting PTEN, RECK and Bcl-2. Oncol. Rep. 2015, 33, 2829-2836. [CrossRef] [PubMed]

246. Zhang, Y.; Wei, Y.; Zhu, Z.; Gong, W.; Liu, X.; Hou, Q.; Sun, Y.; Chai, J.; Zou, L.; Zhou, T. Icariin enhances radiosensitivity of colorectal cancer cells by suppressing NF- $\mathrm{B}$ activity. Cell Biochem. Biophys. 2014, 69, 303-310. [CrossRef] [PubMed] 
247. Carrasco-Leon, A.; Ezponda, T.; Meydan, C.; Valcárcel, L.V.; Ordoñez, R.; Kulis, M.; Garate, L.; Miranda, E.; Segura, V.; Guruceaga, E. Role of lncRNAs as prognostic factor and potential therapeutic target in Multiple Myeloma. Clin. Lymphoma Myeloma Leuk. 2019, 19, e354-e355. [CrossRef]

248. Xiang, Z.; Song, S.; Zhu, Z.; Sun, W.; Sun, S.; Li, Q.S.; Yu, Y.; Li, K.K. LncRNAs GIHCG and SPINT1-AS1 are crucial factors for pan-cancer cells sensitivity to lapatinib. Front. Genet. 2019, 10, 25. [CrossRef]

249. Tsang, S.; Patel, T.; Yustein, J.T. Long non-coding RNAs regulation of therapeutic resistance. Cancer Drug Resist. 2019, 2, 550-567. [CrossRef]

250. Sheng, S.-R.; Wu, J.-S.; Tang, Y.-L.; Liang, X.-H. Long noncoding RNAs: Emerging regulators of tumor angiogenesis. Future Oncol. 2017, 13, 1551-1562. [CrossRef]

251. Zhou, Y.; Zhang, X.; Klibanski, A. MEG3 noncoding RNA: A tumor suppressor. J. Mol. Endocrinol. 2012, 48, R45-R53. [CrossRef]

252. Moradi, A.; Naiini, M.R.; Yazdanpanahi, N.; Tabatabaeian, H.; Nabatchian, F.; Baghi, M.; Azadeh, M.; Ghaedi, K. Evaluation of The Expression Levels of Three Long Non-Coding RNAs in Multiple Sclerosis. Cell J. 2020, 22, 165-170.

253. Shao, F.; Huang, M.; Meng, F.; Huang, Q. Circular RNA signature predicts gemcitabine resistance of pancreatic ductal adenocarcinoma. Front. Pharmacol. 2018, 9, 584. [CrossRef]

254. Kun-Peng, Z.; Xiao-Long, M.; Lei, Z.; Chun-Lin, Z.; Jian-Ping, H.; Tai-Cheng, Z. Screening circular RNA related to chemotherapeutic resistance in osteosarcoma by RNA sequencing. Epigenomics 2018, 10, 1327-1346. [CrossRef]

255. Yu, W.; Peng, W.; Sha, H.; Li, J. Hsa_circ_0003998 promotes chemoresistance via modulation of miR-326 in lung adenocarcinoma cells. Oncol. Res. Featur. Preclin. Clin. Cancer Ther. 2019, 27, 623-628. [CrossRef]

256. Shang, J.; Chen, W.-M.; Wang, Z.-H.; Wei, T.-N.; Chen, Z.-Z.; Wu, W.-B. CircPAN3 mediates drug resistance in acute myeloid leukemia through the miR-153-5p/miR-183-5p-XIAP axis. Exp. Hematol. 2019, 70, 42-54.e43. [CrossRef]

257. Huang, X.; Li, Z.; Zhang, Q.; Wang, W.; Li, B.; Wang, L.; Xu, Z.; Zeng, A.; Zhang, X.; Zhang, X. Circular RNA AKT3 upregulates PIK3R1 to enhance cisplatin resistance in gastric cancer via miR-198 suppression. Mol. Cancer 2019, 18, 71. [CrossRef]

258. Selvam, C.; Mutisya, D.; Prakash, S.; Ranganna, K.; Thilagavathi, R. Therapeutic potential of chemically modified si RNA: Recent trends. Chem. Biol. Drug Des. 2017, 90, 665-678. [CrossRef]

259. Steichen, S.D.; Caldorera-Moore, M.; Peppas, N.A. A review of current nanoparticle and targeting moieties for the delivery of cancer therapeutics. Eur. J. Pharm. Sci. 2013, 48, 416-427. [CrossRef] [PubMed]

260. Kramps, T.; Probst, J. Messenger RNA-based vaccines: Progress, challenges, applications. Wiley Interdiscip. Rev. RNA 2013, 4, 737-749. [CrossRef]

261. Tatiparti, K.; Sau, S.; Kashaw, S.K.; Iyer, A.K. siRNA delivery strategies: A comprehensive review of recent developments. Nanomaterials 2017, 7, 77. [CrossRef]

262. Dammes, N.; Peer, D. Paving the road for RNA therapeutics. Trends Pharmacol. Sci. 2020, 41, 755-775. [CrossRef]

263. Sugawa, H.; Smith, E.; Imura, H.; Mori, T. A thyroid cancer specific monoclonal antibody which recognizes cryptic epitope (s) of human thyroglobulin. Mol. Cell. Endocrinol. 1993, 93, 207-211. [CrossRef]

Publisher's Note: MDPI stays neutral with regard to jurisdictional claims in published maps and institutional affiliations.

(C) 2020 by the authors. Licensee MDPI, Basel, Switzerland. This article is an open access article distributed under the terms and conditions of the Creative Commons Attribution (CC BY) license (http://creativecommons.org/licenses/by/4.0/). 